\title{
57. MARGIN PALEOENVIRONMENTS OF THE NORTHEAST ATLANTIC
}

\author{
D.G. Roberts, Institute of Oceanographic Sciences, Wormley, Godalming, Surrey, U.K. \\ and \\ L. Montadert, Institut Français du Pétrole Rueil-Malmaison, France
}

\section{INTRODUCTION}

Sediments of passive continental margins represent a complex and possibly unique record of the changing paleoenvironment of the oceans, the continents, and also the birth and growth of the oceans. In a broad sense, the paleoenvironment of oceans and continents can be viewed as controlling both the completeness and nature of the lithostratigraphic record shown by the presence or absence of hiatuses, and the lithologic changes between shelf, slope and rise sediments. The sedimentary record is, however, defined by a complex matrix of variables that modify in both space and time not only the accumulation of sediments, but also the relative proportions of terrigenous and biogenous sediments. Among the more obvious of these variables are climate, the altitude of the continents, the fertility of ocean water, and the intensity of ocean circulation. These, and the myriad other factors that fashion the geological record, cannot be separated easily because they may be closely dependent on each other. For example, the climate of the continental hinterland will be determined by its area and orography as well as the climate of the adjacent ocean. In a final, and perhaps extreme analysis, oceanic environments have been said to be shaped by plate tectonics and attendant ramifications (Berger and Winterer, 1974) because the succession of environments in the ocean basins may devolve from changes in ocean basin geometry and inter-basin communication. Although this view is perhaps too general, only a few mechanisms may cause the major variations in the facies of margin sediments. For example, changes in the intensity of the surface and bottom water circulation may lead to changes in sediment accumulation rates, enrichment of waters in nutrients (due to increased residence time), increased biological productivity in upwelling areas and hence to changes in the carbonate compensation depth. Other important factors that may result in profound changes in circulation, and nutrient and oxygen supply, include global changes in sea level, water exchange from higher latitudes resulting from changes in plate motions, and/or the subsidence of sills. Such effects may enhance latitudinal and longitudinal oceanographic and faunal gradients. Their magnitude and effect may also be variable on a margin that is exposed through subsidence to different water masses, themselves variable with time and depth.

In the North Atlantic Ocean, there have been great changes in margin paleoenvironments due not only to local events, but also to global changes in ocean basin geometry and climate. These local events include the construction and subsidence of the various sills between the Arctic Ocean and the Atlantic Ocean, and a complex spreading history that has led to the creation of various parts of its margins at different times and to the isolation of microcontinents such as the Rockall Plateau (Sclater et al., 1977). The complex morphology of the North Atlantic basins and basin margins is likely to have radically influenced the input and distribution of terrigenous sediments and the effects of ocean circulation changes during the Cenozoic that arose from climatic changes.

In this paper, we have not attempted a detailed synthesis of Mesozoic and Cenozoic paleoenvironments in the North Atlantic. Such a synthesis, though clearly desirable, would require a thorough analysis of all DSDP and other relevant data for the entire North Atlantic region that lies beyond the scope and purpose of this Initial Report. The paper is, therefore, restricted to a brief review of the present North Atlantic circulation and its influence on passive margin sediment distribution, and a wider discussion of Cenozoic and Mesozoic paleoenvironments and their influence on northeast Atlantic passive margin stratigraphy.

\section{PRESENT NORTH ATLANTIC CIRCULATION AND SEDIMENT DISTRIBUTION}

The present-day surface circulation of the Atlantic, north of the Azores, is dominated by the northeastward flowing North Atlantic current. In the vicinity of the Rockall Plateau at $55^{\circ} \mathrm{N}$, the current turns northwest and then to the north and east (Sverdrup et al., 1942; Lee, 1974; Worthington and Wright, 1970). Oceanographic surveys clearly show that low salinity water from the Labrador Sea, carried eastward by the surface layers, forms the deep water that overlies the seabed at $59^{\circ} \mathrm{N}, 19^{\prime} \mathrm{W}$ and lies in midwater at $52^{\circ} 30^{\prime} \mathrm{N}$, $20^{\circ} 00^{\prime} \mathrm{W}$. In the Atlantic north of $52^{\circ} 00^{\prime} \mathrm{N}$, the deep circulation is dominated by cold dense bottom water derived from the Norwegian Sea (Lee and Ellett, 1967; Worthington, 1970; Worthington and Wright, 1970). The warm saline water of the North Atlantic current flows northward into the Norwegian Sea where it cools and sinks ultimately to flow back into the North Atlantic across a series of sills between Greenland and Scotland (Figure 1). The principal overflow takes place across the Iceland-Faeroes Ridge, through the Faeroe Bank Channel and Denmark Strait, and across the Wyville-Thomson Ridge (Worthington, 1970; Crease, 1965; Ellett and Roberts, 1973). The volumetrically most important overflow (through the Faeroe Bank Channel and across the Iceland-Faeroes Ridge) turns westward and then southwestward to mantle the eastern flank of the Reykjanes Ridge. Deposition of sediments entrained by the bottom flow has led to the growth of the Gardar Ridge sediment drift (Johnson et al., 1971; Ruddiman, 1972). The southward flowing water ultimately turns westward through the Gibbs Fracture Zone, and other gaps in the Reykjanes Ridge 


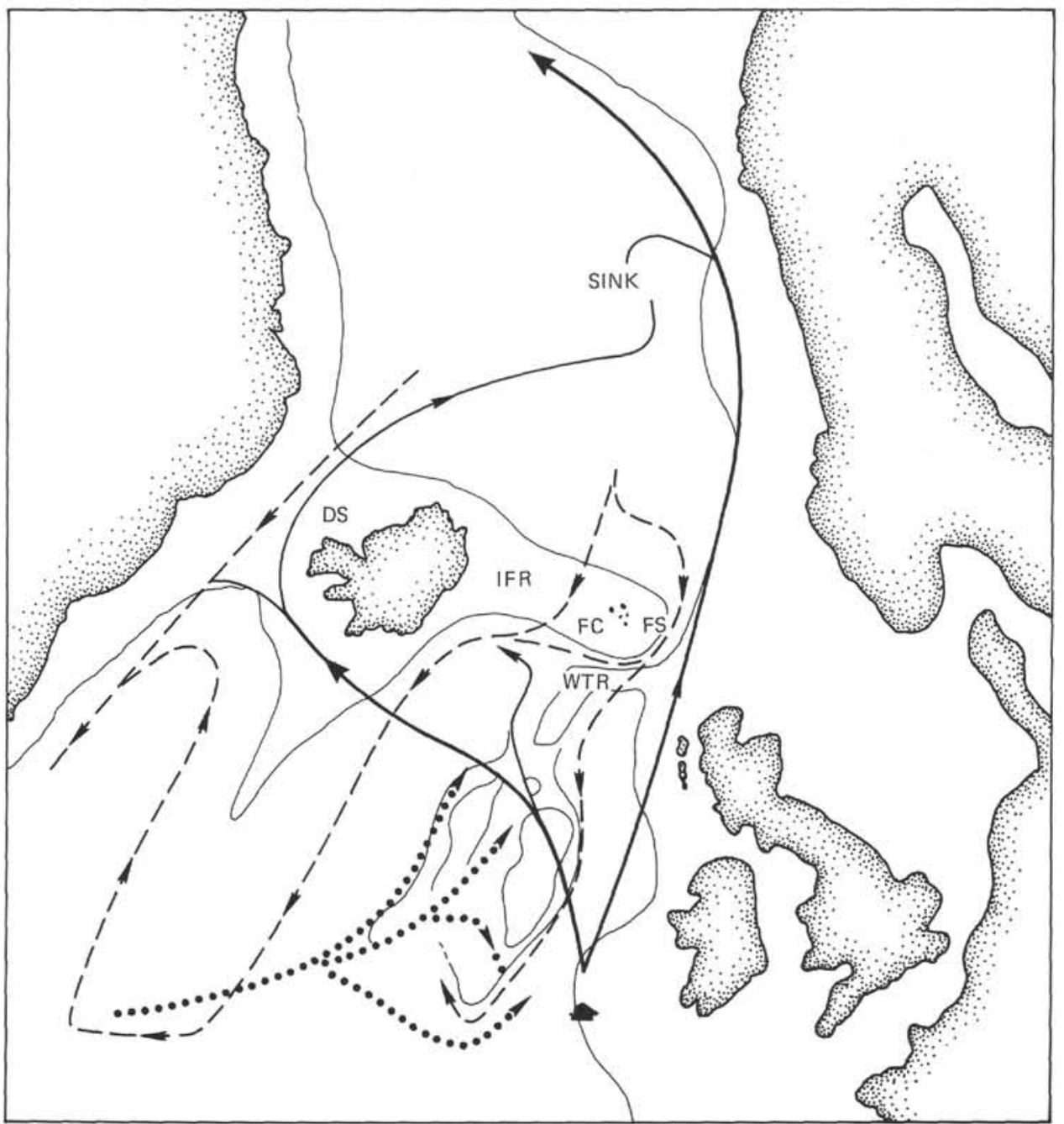

Figure 1. Northeast Atlantic circulation. Heavy solid lines inflow: dashed line, Norwegian Sea overflow, dotted line Labrador Sea water. DS: Denmark Strait, IFR: IcelandFaeroe Ridge; F.C.: Faeroe Bank Channel; WTR: Wyville Thomson Ridge (after Worthington, 1970).

to enter the Labrador and Irminger seas where much of the relief has been fashioned by the erosional and depositional effects of the current (Jones et al., 1971; Johnson et al., 1975; Featherstone et al., 1977). Intermittent overflow across the Wyville-Thomson Ridge has led to the growth of the Feni Ridge sediment drift in the Rockall Trough (Jones et al., 1971; Ellett and Roberts, 1973; Roberts, 1975). This overflow may turn northward around the southern end of the Rockall Plateau to contribute to the erosion and differential deposition observed at Sites 405 and 406 (Roberts, 1975; Site Chapter, this volume). Sediment drifts observed at Sites 403 and 404 form part of the Hatton Drift extending along the western margin of Rockall Plateau and have been associated with northward-flowing Labrador Sea water (Ruddiman, 1972; Roberts, 1975).

In the Bay of Biscay, the deep water mass at Site 400 is North Atlantic deep water and at Sites 401 and 402 it is North Atlantic deep water strongly mixed with Mediterranean water. The surface circulation of the bay has been previously considered as part of the North Atlantic Drift (Dietrich, et al., 1975). However, long-term current obser- vations (Swallow et al., 1977) have documented a poleward-flowing eastward boundary current the influence of which extends beyond the well-known core of Mediterranean water and may extend through the whole water column. This current may be responsible for development of the large sediment drift atop the Meriadzek Terrace (Auffret et al., 1975).

\section{TECTONIC HISTORY OF THE NORTH ATLANTIC OCEAN}

It is clear from previous studies that the development and evolution of the ocean basin circulation cannot be properly considered on other than a global basis (Berggren and Hollister, 1974; Fischer and Arthur, 1977). Events in the southern oceans or Caribbean may be as indelibly printed on the sedimentary record of the Atlantic as they are in that of the Pacific. The converse is, of course, true and we therefore give here a brief summary of the evolution of the complex North Atlantic and Norwegian basins to illuminate the discussion of margin paleoenvironments. 
To the north of the Azores-Gibraltar lineament, the morphology of the Atlantic Ocean is complex and includes anomalously shallow areas such as the Rockall Plateau, the Iceland-Faeroes Ridge, the Jan-Mayen Ridge, and Vøring Plateau.

Syntheses of the plate tectonic history of the Atlantic Ocean north of the Azores-Gibraltar lineament have been largely based on the identification of magnetic anomalies of Late Cretaceous to Recent age (Figure 2). The history prior to the Late Cretaceous has remained obscure due to the absence of precise geological constraints on the age of opening and the absence of clearly identifiable magnetic anomalies (Williams, 1975; Pitman and Talwani, 1972; Kristoffersen, 1978; Roberts and Jones, 1975).

Results presented herein (Montadert, Roberts, et al., this volume) show that spreading was initiated in the Bay of Biscay in Aptian time following rifting in Late $\mathrm{Ju}$ rassic/Early Cretaceous that created some 2000 meters of submarine relief. Rifting and spreading to the west of Portugal may have been coeval although the geometric relationship to the Biscay opening is not understood in part because of the effects of the later Pyrenean deformation (Le Pichon et al., 1977). Seismic profiles to the west of the Goban Spur suggest that the pre-anomaly 31-32 ocean crust abutting the margin is younger than that in Biscay. Roberts and Jones (1975) and Kristoffersen (1978) have suggested that this crust and that in the Rockall Trough was formed during the Late Cretaceous normal polarity interval. By Late Cretaceous time, spreading of uncertain speed and direction had created the Rockall Trough, Bay of Biscay, and part of the ocean crust between the Grand Banks and Portugal (Williams, 1975; Kristoffersen, 1978; Roberts and Jones, 1975). The Late Cretaceous magnetic anomalies cut across those observed in the Bay of Biscay indicating that a major change in spreading geometry took place between Aptian and Late Cretaceous time. This change may be

125 m.y.

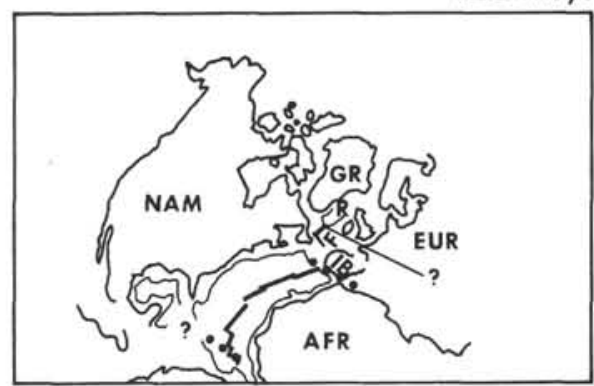

95 m.y.

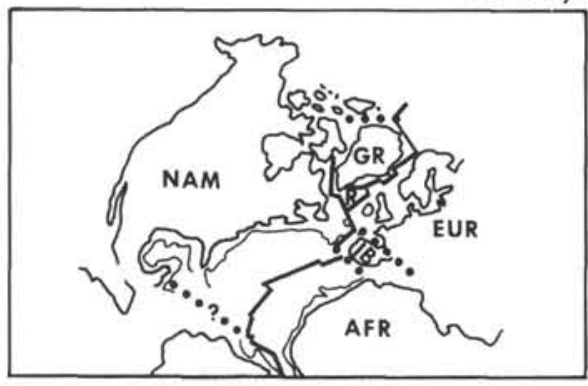

65 m.y.

36 m.y.
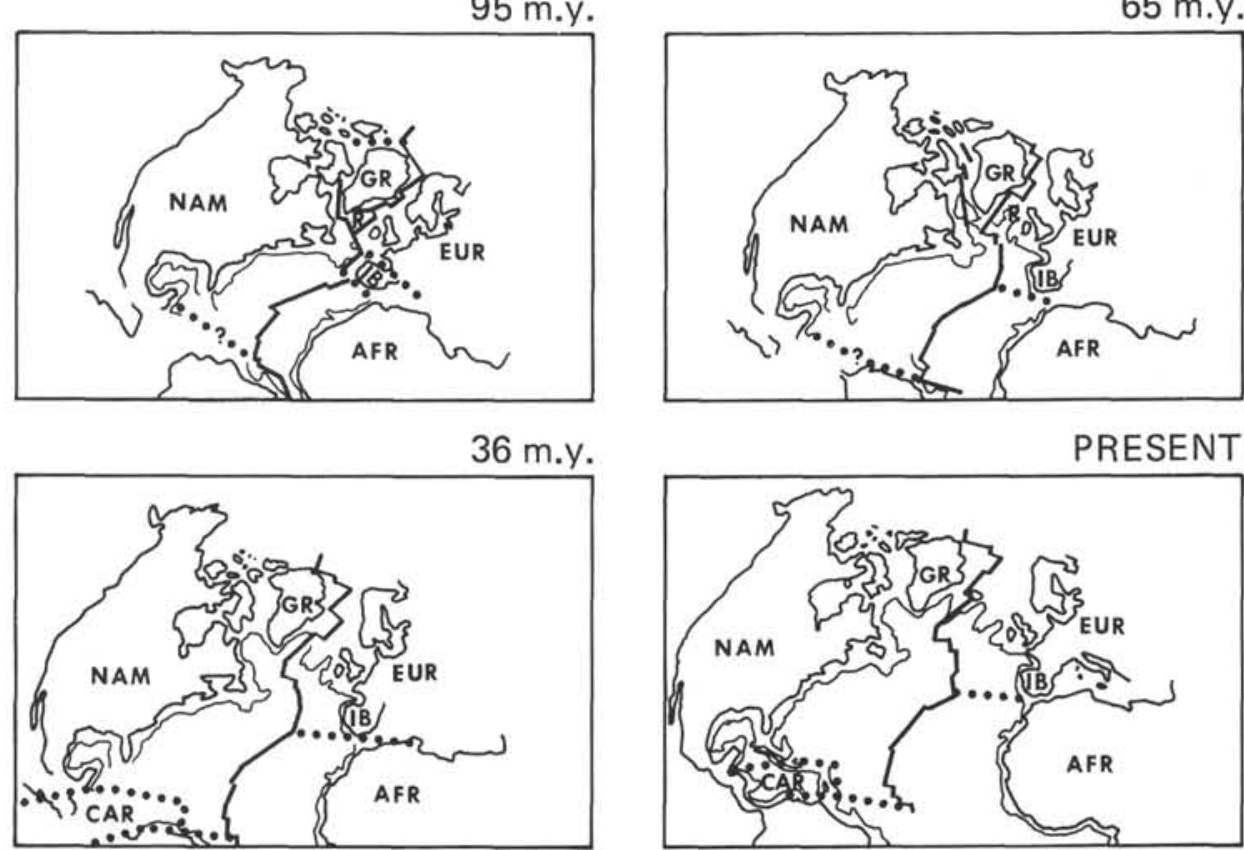

Figure 2. Tectonic history of the North Atlantic Ocean at selected epochs. NAM, GRE, EUR, CAR, IB, AFR, F, R represent, respectively, North America, Greenland, Eurasia, the Caribbean, Iberia, Africa, Flemish Cap and Ophan Knoll, and Rockall Plateau. The 200-meter contour is shown. Heavy line represents a spreading center and dashed lines plate boundaries of unknown geometry. 
related to the initiation of the Pyrenean deformation in Late Cretaceous time (Le Pichon et al., 1977). A major change in spreading geometry took place in anomaly 31-32 time (anomaly 34 time according to Kristoffersen [1978]) when the spreading axis shifted westward to the line of the embryonic south Labrador Sea, creating the Gibbs fracture zone and the rectilinear southwest margin of the Rockall Plateau; uninterrupted spreading continued however to the south of the Gibbs fracture zone (Le Pichon et al., 1972; Laughton, 1972; Olivet et al., 1974; Roberts, 1974; Srivastava, 1978). Rifting between Greenland and the Rockall Plateau during Paleocene time was followed by spreading and the creation of an R-R-R junction between Greenland, Rockall, and Labrador at $52 \mathrm{~m}$.y. Spreading continued in the Labrador Sea until $42 \mathrm{~m}$.y. when the axis became extinct (Vogt and Avery, 1974; Srivastava, 1978; Kristoffersen, 1978). On the Reykjanes Ridge, the spreading decelerated at $38 \mathrm{~m} . \mathrm{y}$. and reoriented to a north-south axis cut by many east-west fracture zones. Spreading continued about this axis until $10 \mathrm{~m}$.y. when a further reorientation and acceleration led to the formation of the present Reykjanes Ridge (Vogt and Avery, 1974). To the south of the Gibbs fracture zone, a complex plate boundary may have extended from the Pyrenees via the Azores-Biscay Rise and King's Trough to the ridge axis from Late Cretaceous to Oligocene/Miocene time (Searle and Whitmarsh, 1978; Roberts and Jones, 1975). The evolution of the Norwegian and Greenland Seas has been in contrast more complex. Although Talwani and Eldholm (1977) assert that spreading did not begin in the Norwegian Sea until 52 m.y. ago, a major rifting episode of Late Jurassic/Early Cretaceous age has been documented in East Greenland (Surlyk, 1978; Birkelund and Perch-Nielsen, 1976). This rifting episode may have been followed by spreading which created the Rockall Trough and its northward continuation in the Norwegian Sea, possibly beneath the inner part of the Vøring Plateau. At 52 m.y., spreading began about the Aegir Ridge in the Norwegian Basin. At 47 m.y., a connection was established between the Norwegian and Greenland seas, and at $37 \mathrm{~m} . \mathrm{y}$. a connection to the Arctic was established via the Knipovitch Ridge. Spreading terminated on the Aegir Ridge at 47 m.y. when the axis shifted westward, hoving off the Jan Mayen Ridge from East Greenland. The final phase of spreading began at about $10 \mathrm{~m}$.y. with a further westward shift of the spreading axis to its present location north of Iceland (Talwani and Eldholm, 1976; Talwani, Udintsev, et al., (1976).

The development of the Iceland-Faeroes Ridge in relation to the spreading histories recorded in the Iceland Basin to the south and the Norwegian Basin is not known because oceanic magnetic anomalies have not been observed over the Ridge (Bott et al., 1971). However, geophysical studies have shown that it is underlain by a thickened oceanic crust flanked to the east by a microcontinent underlying the thick Paleogene lavas of the Faeroes (Bott et al., 1974). Drilling at Site 336 on the Iceland-Faeroes Rise has yielded subaerial basalt dated at $40.4 \pm 3.2$ or $43.4 \pm 3.3 \mathrm{~m}$.y. (Talwani, Udintsev, et al., 1976). Geological and geophysical studies suggest that the Iceland-Faeroes Ridge was formed as a subaerial ridge by spreading between 52 and $27 \mathrm{~m} . \mathrm{y}$.
(Talwani and Eldholm, 1976). Since 27 m.y., the Iceland-Faeroes Ridge and adjacent sills have subsided below sea level (Vogt, 1972; Talwani, Udintsev, et al., 1976; Thiede, in press). Since the present North Atlantic deep water circulation is largely controlled by overflow of water from the Norwegian Sea across this ridge, the timing of the subsidence is of critical importance in the initiation of the overflow.

To the south of the Azores-Gibraltar line, spreading began in Early Jurassic time. Events of global importance include the opening of communication between the North and South Atlantic oceans ( $\sim 100$ m.y., Rabinowitz and La Brecque, in press), closure of the Panama Isthmus, and the closure of the western Tethys at about 15 m.y. (Berggren and Hollister, 1971). Events in the Southern Ocean reviewed recently by Kennett (1977) are discussed below.

\section{ASPECTS OF MESOZOIC PALEOENVIRONMENTS}

During Leg 48, Mesozoic sediments were penetrated at Holes 400A, 401, and 402A, drilled in North Biscay (Montadert, Roberts, et al., this volume). The oldest Mesozoic sediments were cored at Site 401 and comprised Kimmeridgian/Portlandian shallow water limestones deposited either on the crests of tilted fault blocks or in the epicontinental basin that predated the rifting. The Cretaceous section is of most interest because "carbonaceous shales" of Aptian/Albian age were recovered at sites situated in deep and shallow water environments and because of the hiatus between the Cenomanian and early Campanian found in deep and shallow sites alike.

\section{The Aptian/Albian "Black Shales"}

The northeast Atlantic, no less than other ocean basins, is characterized by the widespread distribution of carbonaceous sediments over certain intervals of geological time. Such sediments are known from the Upper Jurassic, the Aptian/Albian, and from the Cenomanian/Turonian. Studies of basinal sequences now exposed on land and DSDP material have led to a variety of hypotheses that attempt to explain the "black shale" phenomena on a worldwide basis and also have fundamental paleoenvironmental implications.

Schlanger and Jenkyns (1976) have interpreted the Aptian/Albian and Cenomanian/Turonian black shales as a product of worldwide anoxic events. Such events may have been a consequence of the Late Cretaceous transgression which increased the area of the epicontinental seas and was accompanied by an increase in the production of organic carbon, or an equable global climate reduced bottom and surface water temperatures leading to a decrease in the supply of oxygenated bottom water. This combination favored the formation of an expanded oxygen minimum layer (OML).

Ryan and Cita (1977) emphasized the different origins of Lower Cretaceous black shales. Although some are of terrestrial origin, others are true pelagic black shales deposited possibly as a result of an oxygen deficiency in oceanic deep waters. They proposed a mechanism of oxygen-depletion linked to climate and decreased thermal gradients in the ocean. Physical barriers may have been important and correlation of euxinic phases with the 
outbuilding of river deltas may have been a consequence of atmospheric depletion in $\mathrm{CO}_{2}$ and the resulting decrease in the heat retention of the atmosphere. They note, however, that deposition of black shales and sapropels may not be connected phenomena.

In the South Atlantic, Thiede and van Andel (1977) and van Andel et al. (1977) noted two phases of anoxic black mudstone deposition in Albian and Santonian time which they considered to result from a strong oxygen-minimum in midwater caused either by excess surface fertility or old, slow moving bottom water.

Fischer and Arthur (1977), from a study of secular variations in the pelagic realm, proposed that deposition of black shales took place during " polytaxic" episodes characterized by maximum diversity of the pelagic biota, lower temperature gradients due to higher and more uniform temperatures, widespread anaerobic conditions, eustatic rises in sea level, and an elevated carbonate compensation depth (CCD). Oligotaxic episodes are, in contrast, characterized by higher temperature gradients due to lower bottom and surface water temperatures, numerous hiatuses, a low CCD and more oxygenated conditions.

In these hypotheses, the nature of the organic matter is rarely taken into account, even if the role of terrestrial input is recognized (e.g., Ryan and Cita, 1977). A marine origin is usually accepted with the implicit and automatic assumption that preservation of the organic matter is due to reducing conditions.

The discovery of Albian/Aptian black shales at two sites in the Bay of Biscay was by no means unusual or unexpected. However, results from the sites are of interest because the black shales were deposited in very different paleodepths on a passive margin and also because of the implications of the results of shipboard pyrolysis studies and subsequent shoreside organic geochemical studies.

The Aptian and Albian beds of Hole 400A consist of a rhythmic sequence of between 30 and $50 \mathrm{~cm}$ in thickness. From the base to the top (Figure 3), each sequence typically consists of: (a) a calcareous mudstone $(10-100 \mathrm{~cm}$ in thickness) resting on an erosion surface; intense bioturbation is confined to the uppermost 20 to $30 \mathrm{~cm}$. (b) bioturbated, black carbonaceous claystone (10-20 cm thick). (c) dark, laminated, silty claystones that are typically a few centimeters in thickness but may not always be present.

A decrease in $\mathrm{CaCO}_{3}$ content towards the top of each sequence is marked by increasing dissolution of the calcareous plankton and an increase in radiolarians. The organic content is greater than 0.5 per cent in the black carbonaceous and silty claystones and may be as much as 3 per cent.

The sedimentological characteristics of these deposits suggest that the calcareous mudstones were emplaced as very fine grained turbiditic flows in basinal conditions (de Graciansky et al., this volume). Emplacement of these flows was probably instantaneous in comparison to the several ten thousand year duration of each sequence estimated from sedimentation rates and the number of sequences. Only the upper part of the most recently deposited sediments was therefore subjected to bioturbation by burrowing organisms.

The clear correlation between low $\mathrm{CaCO}_{3}$ content (around 5\%) and the dissolution of calcareous microfossils

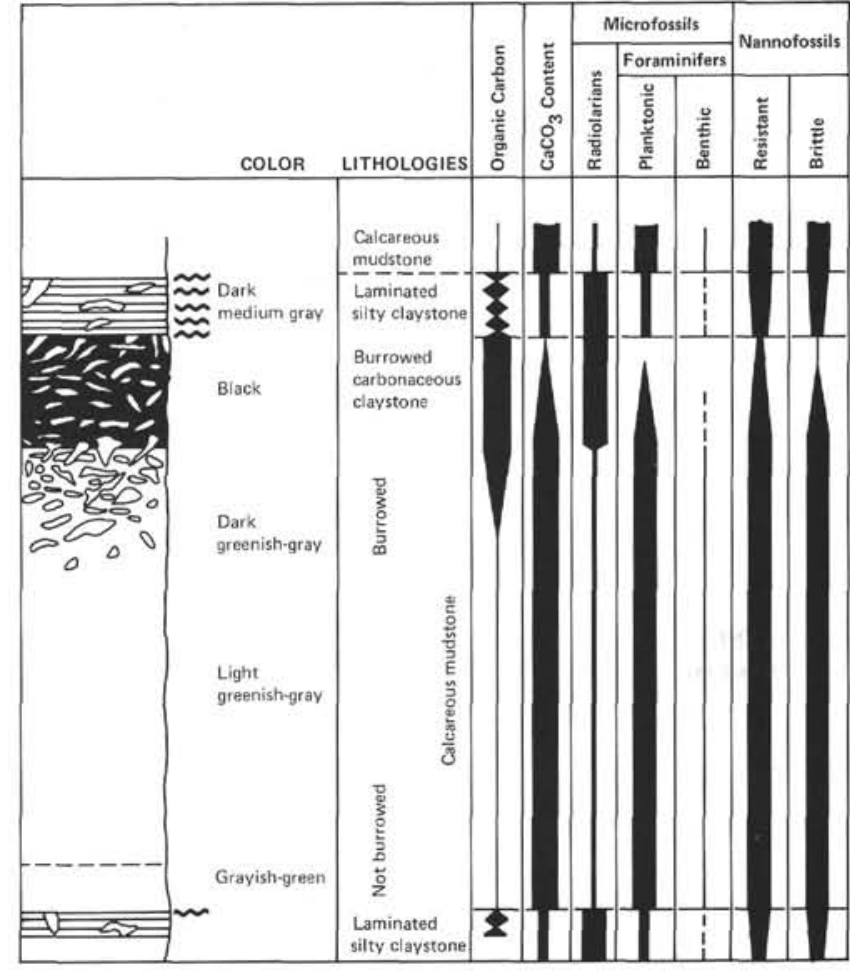

Figure 3. Diagrammatic section of a type sequence in the lower Albian and upper Aptian of Hole $400 \mathrm{~A}$ (from de Graciansky et al., this volume).

in the upper part of the turbidite sequence shows that sedimentation took place close to the calcite compensation depth. The thin layers of carbonaceous claystone are, therefore, considered to represent normal autochthonous pelagic sediments. From an analysis of the seismic reflection data (Montadert et al., this volume), deposition is estimated to have taken place in a 1500 and 2000 meters deep trough during, and shortly after, rifting.

Comparable alternating sequences of Cretaceous age are well known in the western Alps and have previously been interpreted in terms of rhythmic or frequent climatic changes, although latterly a turbiditic origin has been clearly shown (Beaudoin, 1977). In these deposits, and those of Hole 400A, the lack of graded bedding is due to the fine grain of the sediment contained within the flow. At Site 398 (de Graciansky et al., in press), comparable Albian black shales clearly show graded bedding. Although this interpretation is preferred, Mélières (this volume) has alternatively proposed that the "rhythmicity" may be due to changes in dissolution rates.

Pyrolysis, paleontological, and geochemical studies of the organic matter (Batten, this volume; Davey, this volume; Deroo et al., this volume) show that it is typically of terrestrial origin since the kerogen is type BII of the well-known series of organic matter (Tissot et al., 1964). The analytical data also show that this terrestrial matter probably suffered intense weathering and oxidation in subaerial soils. The organic matter is also mainly composed of recycled or derived organic matter besides contemporaneous material. 
At Hole 402A, in marked contrast, the Aptian/Albian black shales were deposited at the front of two superimposed depositional sequences prograding over a carbonate platform. Each sequence suggests an upslope trend and from the bottom to the top consists of: (a) slumped marly limestones and calcareous mudstones corresponding to an accumulation near the foot of the then paleoslope; (b) interbedded graded and slumped beds that correspond to deposition on the slope; (c) hard grounds, relatively coarse packstones and grainstones characteristic of the upper slope and/or outer shelf.

This facies model is supported by the nature of the biogenic components; sediments of the basinal facies are rich in ammonites, where echinoderms, red algae, pithonellids, and bryozoa indicate an upper slope/outer shelf environment.

Paleontological data and constraints imposed by the thickness of each prograding unit indicate that the top of the sequence was deposited in 50 to 100 meters water depth and the base between 300 and 400 meters depth.

As at Hole $400 \mathrm{~A}$, the organic carbon is of terrestrial origin and suffered weathering prior to deposition (Deroo et al., this volume). The organic carbon content decreases from 2 to 1 per cent from the base to the top of each sequence. It is important to note that organic matter of marine origin has not been found in Holes 400A and 402A. If results from the two sites can be validly regarded as being representative, reducing conditions, therefore, did not exist in the then narrow youthful Bay of Biscay either on the shelf or in deep water (Figure 4). This conclusion is supported by the intense bioturbation observed at both sites. Even if an OML is postulated to lie midway between the sites, stagnation of the basin is not evident. Our results demonstrate the importance and necessity of describing and defining the nature of the organic matter before discussion of any global implications of black shale deposition.

A wider discussion and interpretation based on this type of analysis has been given by Tissot (in press). Good well

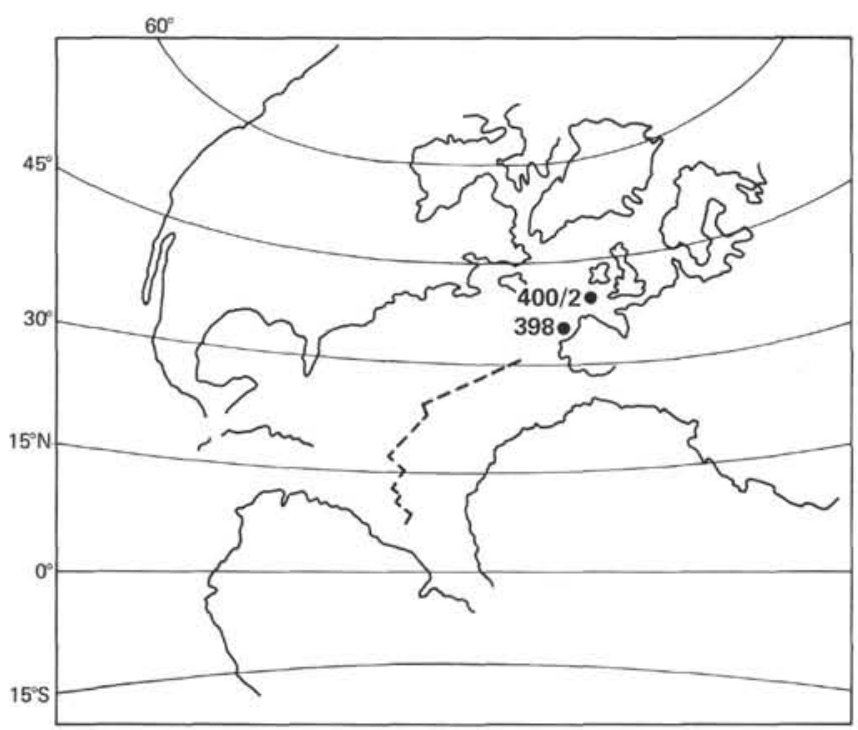

Figure 4. Distribution of North Atlantic continents and oceans in Aptian/Albian time. oxygenated circulation conditions, unfavorable for the preservation of organic matter and similar to those observed in Biscay, apparently prevailed in Aptian/Albian time in the western central North Atlantic. In contrast, extended anoxic layers partly existed in the Eastern Basin and in the Brazil-Angola and Argentine-Cape basins of the South Atlantic.

In Aptian/Albian time, conditions clearly varied from basin to basin. In some cases, an active circulation inhibited preservation of organic matter but, in others, perhaps due to barriers, circulation was restricted and sapropels were laid down. This view is simplistic, however, for within the basins large volumes of terrestrially derived detrital carbon may (or may not) have diluted the marine organic matter. Examples of such areas include the Northeast Atlantic, Western Atlantic, offshore Northwest Africa, and the Argentine-Cape basins. The distribution of marine and detrital organic matter has been explained in part by climatic considerations (Tissot, in press). Areas of high production of terrestrial carbon were situated in a humid tropical zone favorable for the widespread growth of vegetation in flat-lying coastal/estuarine swamps in which the organic matter was altered before being transported seaward. Areas in which preservation of organic matter took place were situated in the arid zone. In this context, analogies between the Red Sea and the closed Aptian South Atlantic are of interest.

In addition to continuing organic geochemical studies on the black shales, the development of the climatic (marine and terrestrial) favoring extensive growth of plants is worthy of further study, perhaps by an analysis of oxygen and carbon isotopes.

\section{The "Cenomanian" Hiatus}

At all three sites in Biscay, a prominent hiatus (Figure 5) is present above the Albian and extends to the late Campanian at Hole 400A and Site 401, and to the Eocene at Hole 402A. At Hole 400A, the hiatus was between the deep water carbonaceous limestones of Aptian/Albian age and deep water chalks of late Campanian age, but at Site 402, it lies between shallow water Albian limestones and deep water Campanian chalks. At Hole 402A, shallow water Albian carbonaceous shales are overlain by deep water Eocene siliceous chalks. In Biscay, the hiatus is at least partly erosional in origin, for older formations are clearly truncated by the unconformity (Figure 6; Montadert, Roberts et al., this volume). During intra Albian/Campanian time, erosion and/or non-deposition, equally affected sites situated in depths of between 100 and 2000 meters. An abnormally shallow CCD at between 1500 and 2000 meters in Aptian time is indicated by dissolution at Hole 400A and, again perhaps, in Campanian/Maestrichtian time. The hiatus is of wider interest, therefore, because it affects shallow and deep water sediments alike and is at least partly contemporaneous with the well-known transgression.

The duration of the hiatus observed in Biscay is much greater than elsewhere in the Atlantic (Ryan, Sibuet, et al., 1977) and statistical studies (Fischer and Arthur, 1977; van Andel et al., 1977) show that the peak of the hiatus occurs in late Turonian time in close coincidence with inde- 
pendent estimates of the highest sea level stance made by Pitman (in press) and Vail et al. (1977). A study of the oceanographic changes, preceding and following the hiatus, is precluded in Biscay by the absence of much of the record. However, because the hiatus is a global phenomenon, compilations of oxygen and carbon isotope data on a worldwide basis are relevant (Savin, 1977; Fischer and Arthur, 1977). These show a general decrease in upper water temperatures in Albian/Cenomanian time, followed by a substantial rise in Turonian and/or Coniacian time. There was then a general fall in temperatures to reach a minimum in the early Maestrichtian. Tertiary paleotemperatures are discussed in the following section. There was also a marked decrease in $\delta^{13} \mathrm{C}$ in Turonian time.

It should be borne in mind that the Turonian sea level rise may have been as much as 350 meters relative to present-day sea level and the effects on climate, circulation and the biota, were probably profound (see Fischer and Arthur, 1977; Charig, 1973). However, in the absence of physical models of the circulation based on adequate quantitative physical paleoceanographic data, cause and effect cannot be separated other than by perhaps unwarranted speculation.

It is, nonetheless, tempting to correlate the erosional event with the rapid rise in sea level between Cenomanian and Turonian time. Development of extensive shelf seas would have resulted in warmer shelf waters that would have cooled as they penetrated to higher latitudes. Production of colder bottom water might have resulted in greater density gradients and, in consequence, stronger currents capable of causing erosion in the deep ocean. These changes would have been rapid in terms of geological time, but $\mathrm{O}^{18}$ analyses across the key stratigraphic intervals are presently inadequate to confirm or deny such changes. However, paleoecological studies support a rapid warming within a single sub-zone of the Turonian (Jefferies, 1963). Another consequence of the greater area of shelf water and warmer temperatures may have to concentrate carbonate production in these areas depleting the oceans in $\mathrm{CO}_{2}$ (cf. $\delta^{13} \mathrm{C}$ fall) leading to a rapid rise in the CCD. Effects on the global wind pattern and its effect in turn on the circulation may well have been profound, but remain speculative. It should be noted that changes in plate motion may have allowed communication between the North and South Atlantic oceans at about $100 \mathrm{~m} . \mathrm{y}$. that may also have modified the circulation (Rabinowitz and La Brecque, in press).

\section{ASPECTS OF CENOZOIC PALEOENVIRONMENTS}

\section{The Paleotemperature Record}

Perhaps the most dramatic evidence of changes in the circulation of the world's oceans is offered by the presence of hiatuses in the deep-sea geological record (e.g., Pimm, Hayes, et al., 1972; Moore, 1972; Davies et al., 1974). Their existence cannot be ascribed to emergence for they usually separate deep water pelagic sediments. Such hiatuses have usually been attributed to erosion and/or non-deposition, and reflect the balance between the rate of sediment supply and its rate of removal by erosion or solution. Hiatuses do not offer a precise measure of the changes in these rates because erosion may have removed the relevant part of the record, although Berger (1970) has pointed out that regional synchronism in the age of an unconformity suggests that the start of the hiatus is close to the age of the underlying sediment. Oxygen isotope paleotemperatures derived from benthic and planktonic foraminifers do provide, however, a record of bottom and surface water temperature variations that can be regarded as monitors of ocean circulation changes. Added to the timing and nature of hiatuses, these data can provide a wider insight into the origin of these stratigraphic breaks. There is a wider interest for detailed studies of the deep-ocean paleotemperature record have not been previously made in these latitudes.

However, some caution must be used in the application of these data because paleotemperatures recorded on a rapidly subsiding margin may reflect exposure to different water masses rather than any major circulation change; ecological effects will also be important (Savin, 1977). Since the paleodepths of Hole $400 \mathrm{~A}$ changed little between the Paleogene and the present (Schnitker, this volume), the relatively complete paleotemperature record obtained at that site probably monitors true changes in surface and deep eastern boundary circulation. Discussion of paleotemperatures and hiatuses is thus based primarily on Hole 400A and the bulk carbonate data from Site 406 (Létolle et al., this volume; Vergnaud-Grazzini et al., this volume).

During Paleocene time, surface and bottom water temperatures were higher than today (Figures 7,8). At, or close to, the Paleocene/Eocene boundary, temperatures increased to subsequently decrease by late Eocene time. The increase in water temperature is coincident with a peak in benthic faunal turnover (Zone P.6) and with a sharp increase in NRM (Schnitker, this volume; Hailwood et al., this volume). Hiatuses began at $54 \mathrm{~m} . \mathrm{y}$. (NP 10) and abruptly ended at 49 m.y. (NP 14). Hiatuses that are apparently associated with these events were also found at Hole 400A and Site 401, and inferred at Site 111 on the Orphan Knoll (Laughton, Berggren, et al., 1971). Coincidence of these events with the onset of spreading between Greenland and Rockall Plateau suggests that the widening of the North Atlantic Ocean allowed penetration of warmer water to higher latitudes as shown by the bryozoan fauna of Rockall Bank (Cheetham and Hakonnsen, 1971). The increase in NRM may reflect wider dispersion of detrital magnetic minerals derived from volcanic rocks associated with the rifting and spreading.

Between early and middle Eocene time (Figures 7, 8), cooling of both surface and deep waters took place in both Biscay and Rockall (Létolle et al., this volume; Vergnaud-Grazzini et al., this volume). The surface cooling may have taken place in a steplike fashion since nannofossil assemblages indicate warmer periods interspersed with cooler periods (Müller, this volume). Rich and diversified palynological assemblages of middle Eocene age also suggest a changing climate (Costa and Downie, this volume). Evidently latitudinal temperature gradients were developed during or after the change, for the decrease was greater at Rockall than in Biscay (Müller, this volume). However, the absence of a contemporaneous fall in the paleotemperature of the continental shelf water of the Eocene North Sea (Buchardt, 1977) (Figure 8) suggests that 


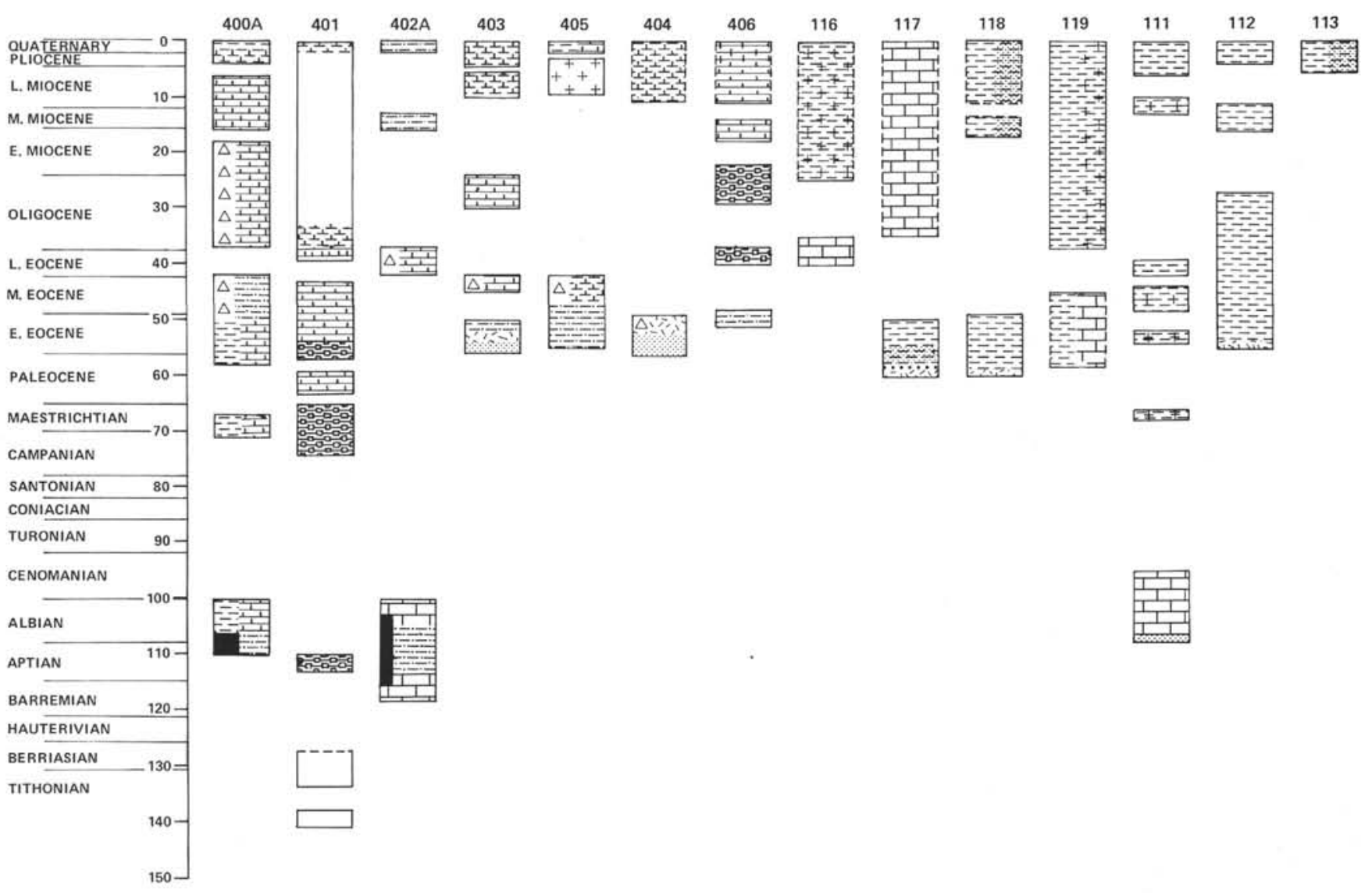

Figure 5. Summary stratigraphy at DSDP sites in the Atlantic north of the Azores-Gibraltar line, per cent of cored intervals containing stratigraphic gaps, $\delta O^{18} \mathrm{PDB}$ (Létolle et al., this volume) and the global sea-level curve of Vail et al., 1977.

the English Channel and southern North Sea may then have been largely isolated from interchange with the Atlantic (cf. Larsonneur, 1972). The Eocene cooling has also been recorded in the South Atlantic in P.11 time (Boersma and Shackleton, 1977). However, the timing of these North Atlantic events precedes the major cooling at the Eocene/ Oligocene boundary observed in the southwest Pacific and Antarctic oceans and widely considered to be of global significance (Shackleton and Kennett, 1975; Haq et al., 1977; Kennett, 1977). An exception is the Eocene/Oligocene decline in North Sea paleotemperatures which is contemporaneous with that recorded for the Southern Ocean. The difference in timing is also reflected in the evolution of benthic microfauna. For example, the diversity of the ostracode fauna increases in middle Eocene time although the most important change occurred in late Eocene time in the Bay of Biscay (Ducasse and Peypouquet, this volume; Schnitker, this volume). The cause of these differences in timing is not clear and may point to the earlier influence of a local "North Atlantic event," rather than events in the Southern Ocean. The middle Eocene cooling is coincident with the opening between Antarctica and Australia, the connection between the Norwegian and Greenland seas, and the end of opening of the Labrador Sea (Kennett, 1977; Talwani and Eldholm, 1976; Srivastava, 1978). In total, these events may have resulted in increased latitudinal temperature gradients and the generation for the first time of bottom water at high latitudes in the North Atlantic. The vertical temperature gradient remained small, however, as there was no connection from the Atlantic to the Norwegian Sea (Thiede, in press). Alternatively, northward penetration of cold bottom water from the South Atlantic may have been limited by distance and topographic barriers. The major cooling, which took place at the Eocene/Oligocene boundary and is recorded in both continental shelf surface and bottom water temperatures, is probably related to the formation of substantial Antarctic Sea ice at 38 m.y. (Kennett, Houtz, et al., 1975). The maximum temperature drop took place in Oligocene time at Zone P.17 at Rockall and in Zone P.22 in Biscay, slightly after the peak in the increase in benthic faunal turnover. Although considerably lower than previously, lower Oligocene paleotemperatures remained higher than in the Pacific (Savin, 1977), indicating the bottom water originating at high southern latitudes was unable to penetrate to the North Atlantic (Boersma and Shackleton, 1977), and surface water temperatures remained higher than those reported for the equatorial Atlantic.

During late Oligocene and early Miocene time, a rise in bottom water temperatures is recorded at Hole 400A. Surface water temperatures also rose and resulted in the northward penetration of warm water species to the Rockall Plateau. A comparable warming has also been observed in 

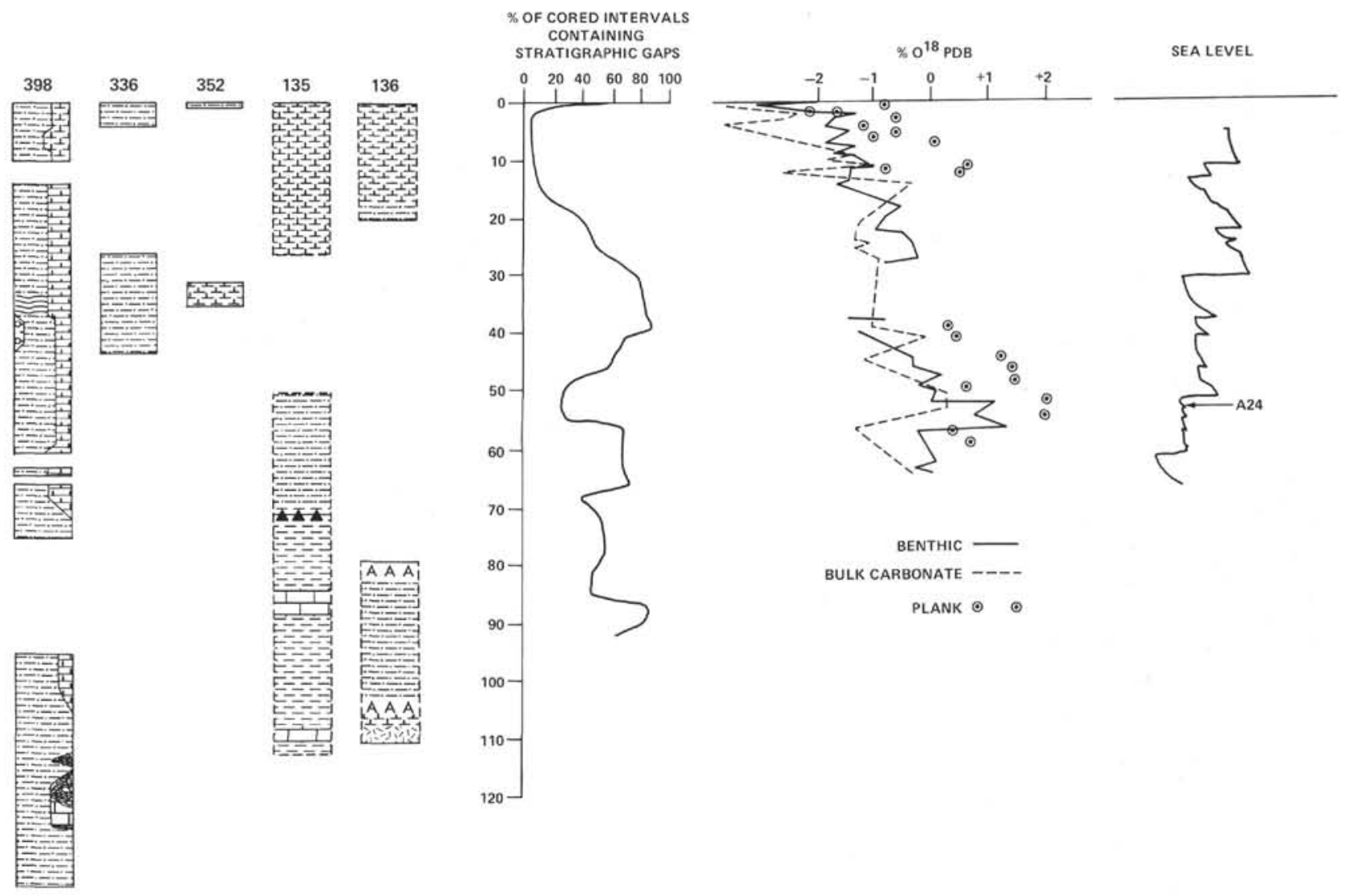

Figure 5. (Continued).

the North Sea (Buchardt, 1977). This event is further recorded by the widespread deposition of nannofossil ooze in the Norwegian Sea and Greenland Sea (Talwani, Udintsev, et al., 1976; Müller, 1976) that shows penetration of Atlantic surface water masses (Müller, 1976). Penetration of the Norwegian Sea may have been achieved by subsidence of the deeper sills of the Iceland-Faeroes Ridge combined with a worldwide transgression (Vogt, 1972; Roberts, 1975; Vail, 1977; Thiede, in press) and may have led to the first production of cold bottom water. Coincidence of these changes with the end of spreading in the Norwegian Basin and the connection of the Norwegian Sea to the Arctic Ocean also suggests that exchange of water to higher latitudes may have then become important.

The decrease in surface and bottom water temperatures between Oligocene and during lower Miocene time has been observed elsewhere in the Atlantic (Boersma and Shackleton, 1977) and may be related to the opening of the Drake Passage between 30 and $22 \mathrm{~m}$.y. (Barker and Burrell, 1977). However, warming followed in late-early and early-middle Miocene. This warming was apparently of global extent and may again be related to a transgression (Vail, 1977). After this time, strong cooling took place at about 13 to $11 \mathrm{~m} . \mathrm{y}$. and may be related to the development of the East Antarctic ice cap (Kennett et al., 1975; Kennett, 1977). Although these events correspond closely in time to the well-documented paleoceanographic events of the southern oceans, they may also have been overprinted by effects arising from changes in the morphology of the North Atlantic Basins (Figure 9). Full exchange of water across the Iceland-Faeroes Ridge is inferred from subsidence criteria to have begun in post-middle Miocene time (Vogt, 1972: Talwani and Eldholm, 1976; Thiede, 1973, in press). These approximate dates lie close to the inferred time of a drop in bottom water temperature in the early-middle Miocene, suggesting that this fall in the Northeast Atlantic arises as a consequence of two factors: development of a greater temperature gradient between the poles and equatorial regions and cooling of surface water now flowing into the Norwegian Sea that led to the production of cold northeast Atlantic deep water. The sharp drop in bottom water temperature in the northeast Atlantic can only be related plausibly to this mechanism because topographic barriers prevent northward passage at the present time of bottom water of Antarctic origin beyond $35^{\circ} \mathrm{N}$ (Worthington and Wright, 1970). The prominent early-middle Miocene hiatus developed at many North Atlantic sites may be related to erosion and/or non-deposition associated with the vigorous bottom circulation that developed following the exchange of water between the Norwegian Sea and the North Atlantic Ocean (Jones et al., 1971; Roberts, 1975). Seismic profiles and lithostratigraphic data (Figure 10) (Roberts, 1975; Roberts et al., this volume) suggest that this bottom circulation has remained similar in pattern, though not necessarily in intensity, to that observed today and has significantly influenced the distribution and deposition of post-middle Miocene sediments. Thick sediment drifts developed at Sites 403, 404, and 406, and the prominent Eocene/Miocene hiatus at Site 405 may be directly attributable to this effect of the regional bottom flow. 

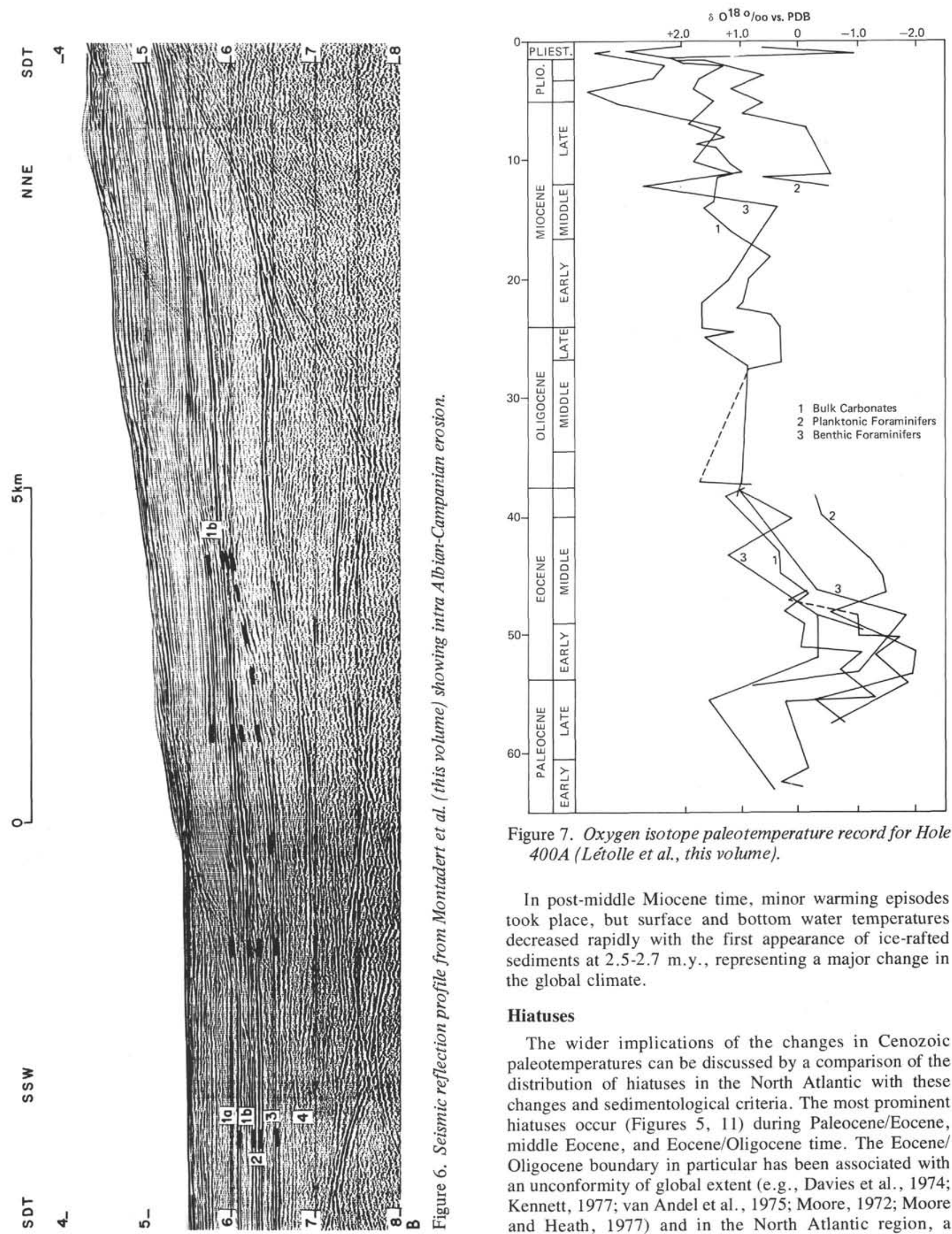

Figure 7. Oxygen isotope paleotemperature record for Hole $400 A$ (Létolle et al., this volume).

In post-middle Miocene time, minor warming episodes took place, but surface and bottom water temperatures decreased rapidly with the first appearance of ice-rafted sediments at 2.5-2.7 m.y., representing a major change in the global climate.

\section{Hiatuses}

The wider implications of the changes in Cenozoic paleotemperatures can be discussed by a comparison of the distribution of hiatuses in the North Atlantic with these changes and sedimentological criteria. The most prominent hiatuses occur (Figures 5, 11) during Paleocene/Eocene, middle Eocene, and Eocene/Oligocene time. The Eocene/ Oligocene boundary in particular has been associated with an unconformity of global extent (e.g., Davies et al., 1974; Kennett, 1977; van Andel et al., 1975; Moore, 1972; Moore and Heath, 1977) and in the North Atlantic region, a 


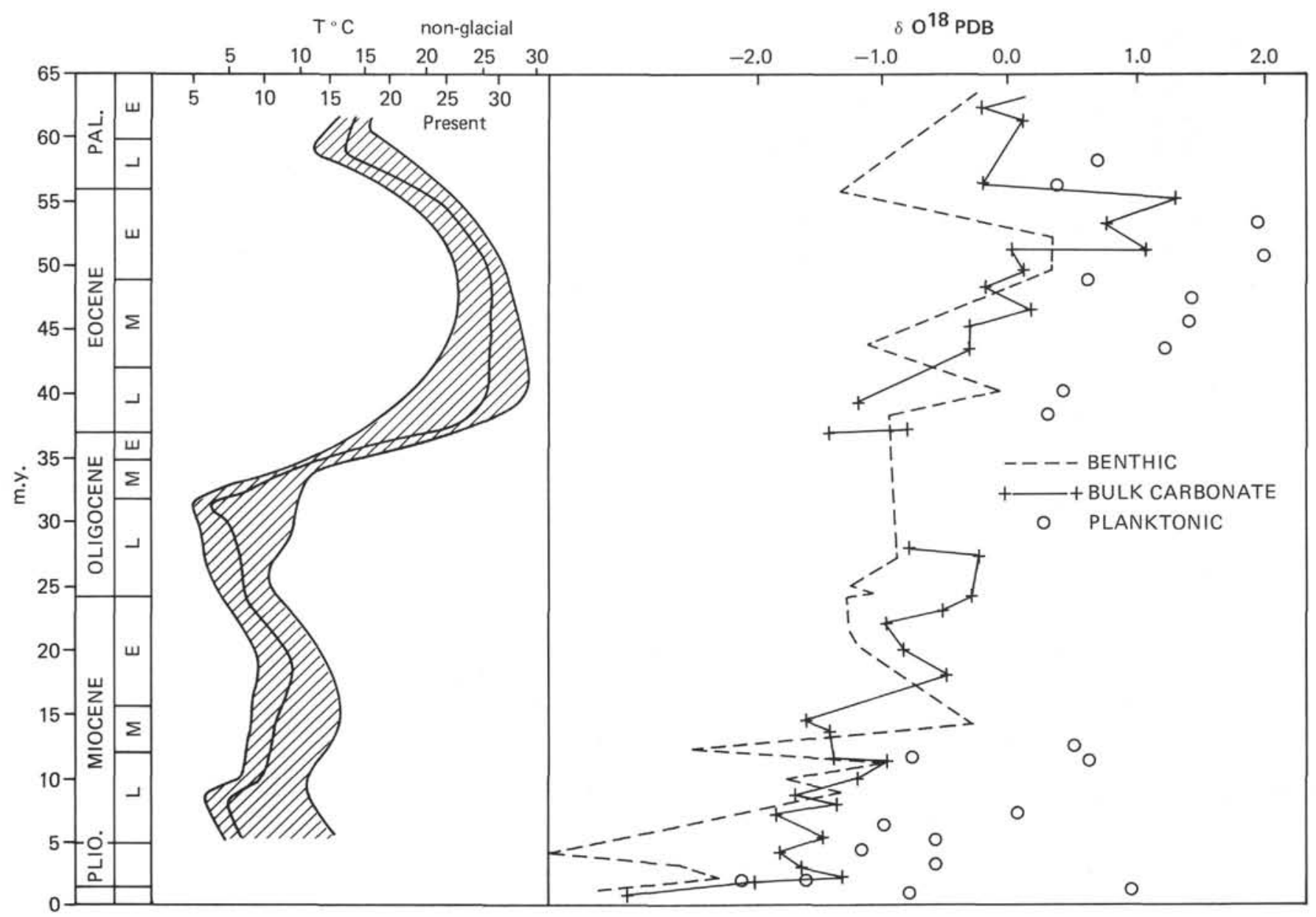

Figure 8. Comparison of $\delta O^{18}$ paleotemperature data from the Bay of Biscay and North Sea. Hachured area for North Sea curves indicates approximate error limits (from Létolle et al., this volume; Burchardt, 1977).

prominent stratigraphic break extending above and below this boundary has been observed at the majority of DSDP sites (Figures 5, 9, 11). The curves suggest that the most complete parts of the record may coincide with intervals characterized by warmer surface and bottom water temperature. This is especially true during Paleocene/ Eocene time and again during Oligocene time. In contrast, the hiatuses seem to coincide with the change from warmer to colder conditions, suggesting that greater temperature (i.e., density) gradients led to intensified circulation and thus erosion, non-deposition, or reduced sedimentation during the overturn.

It is conceivable that the erosional events may have been very rapid since such temperature changes in oceanic water are effectively instantaneous in terms of geological time. In this context, Kennett and Shackleton (1978) have shown that the Eocene/Oligocene temperature change in the South Atlantic took place entirely within 70,000 to $100,000 \mathrm{yr}$ at the Eocene/Oligocene boundary.

In the Bay of Biscay, the change between the early Eocene and middle Eocene is dramatically marked by a change in the color of the sediments from yellowish brown to greenish gray, a decrease in carbonate and NRM (Figure 12). Seismic profiles (Figure 13) also show evidence of an erosional unconformity with the overlying sediments
(Montadert et al., this volume). During the Oligocene, orange and brownish chalks are again dominant, but are succeeded by greenish gray chalks, characterized by weak NRM intensity. Changes in NRM intensity (Figure 12) occur abruptly near the lower middle Eocene boundary and after the early Oligocene in Biscay. Auffret and Pastouret (this volume) indicate a trend of increasing bottom current activity from early to middle Eocene time. Comparable changes also occurred at sites 403-406 on the Southwest Rockall Plateau (Figure 10). For example, the middle-upper Eocene hiatus observed at Site 406 was associated with erosion. Other hiatuses associated with erosion between the Oligocene and Eocene and during the Miocene may also be related to the events discussed above.

One of the main objectives of the passive margin drilling program was to examine the stratigraphic record of passive margins for a relationship between deep-sea hiatuses and those known on the adjacent shelf and land. In Figure 14, the sedimentation history of Leg 48 sites is compared with unconformities recorded on the adjacent shelf, the global sea level curve of Vail et al. (1978), and the spreading history of the North Atlantic. The comparison has been restricted to Leg 48 sites, the adjacent shelf and basins to seek the existence of a simple correlation within a single basin of known age and history. 


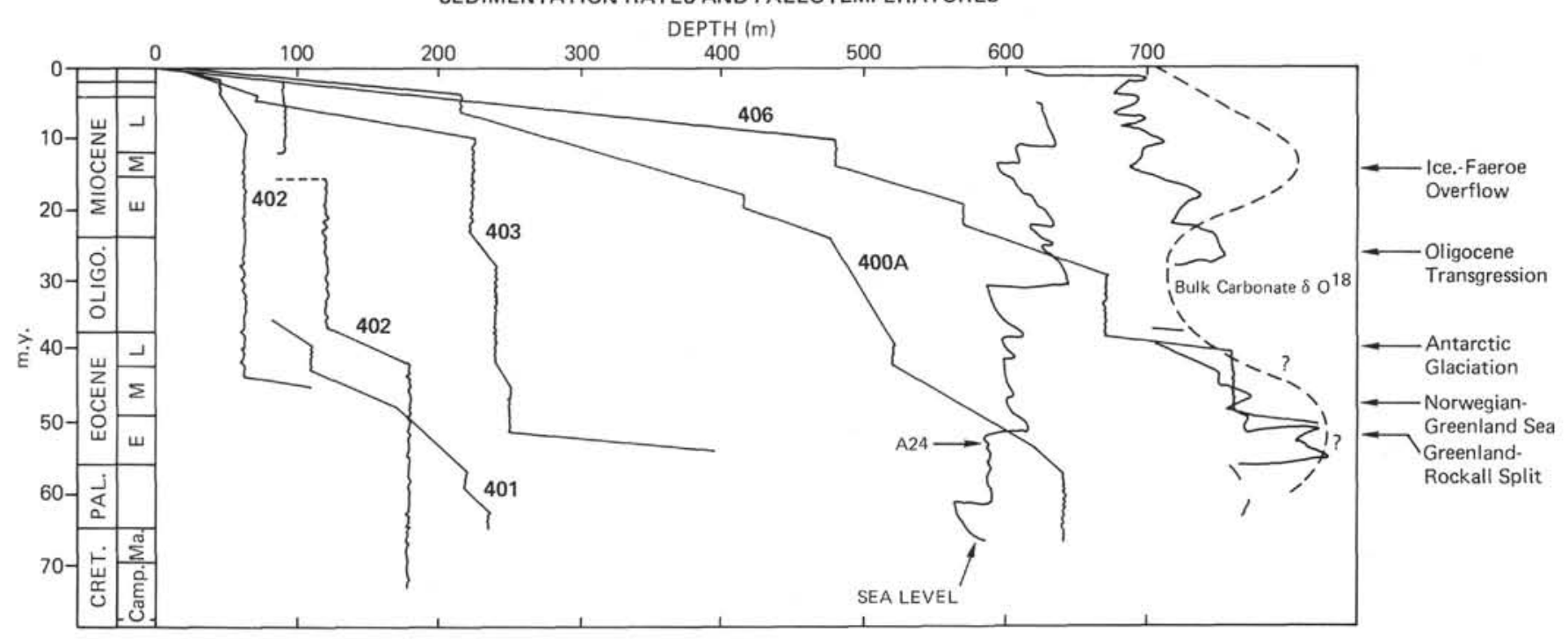

Figure 9. Sedimentation rates and paleotemperatures: dashed line is modified CCD curve of van Andel (1975).

Allowing for the imprecision in defining hiatuses, there appears to be limited evidence of a not unexpected correlation between sea-floor spreading rate changes and sedimentation rate changes, e.g., during early Miocene and during Paleocene/Eocene time. As discussed above, these may plausibly be related to ocean circulation changes arising from changes in plate motions.

To assess the oceanward extent of the warping movements recorded on the shelf, the seismic profiles have been carefully examined for evidence of renewed faulting during the Cenozoic. With the exception of minor shearing observed on the outer part of the rise and in the abyssal plains that may be related to the Pyrenean deformation, no evidence of faulting has been found (Montadert et al., this volume; Roberts et al., this volume). Nonetheless, the pre-Ypresian and pre-Lulétian movements recorded on the shelf appear to correlate with the opening of the Atlantic between Greenland and the Rockall Plateau. The post-early Oligocene folding and regression is less easily related to changes in spreading and rather may be related to the Pyrenean and Alpine deformation. This event may be recorded by the Oligocene/Miocene increase in sedimentation rate. The warping phases also seem to correlate with the global eustatic changes in sea level documented by Vail et al. (1977). Evidence for a correlation between Cenozoic deep-sea hiatuses and events on the shelf is presently weak. However, the correlation between sea-floor spreading rate changes, the global sea level curve of Vail et al. (1977) and the shelf events is sufficiently strong to demand further investigation since it implies that reorganization of plate motions results in renewed warping of the passive margins (possibly in response to compression) further modifying global hyposometry and thus sea level.

\section{Deposition of Biogenic Calcareous and Siliceous Sediments}

The distribution of biogenic calcareous and siliceous sediments in the world's oceans bears a close relationship to the surface circulation and is closely dependent on fertility (Lisitzin, 1972; Berger, 1970). At the present, sediments deposited in regions of high fertility are characterized by the presence of siliceous organisms such as diatoms and/or radiolarians. Their abundance can be regarded as a tracer of fertility because the supply of tests is increased below fertile areas and their preservation is enhanced by the dissolution of the more fragile forms of biogenic carbonate due to increased solution of carbon-dioxide and a lowering of the $p \mathrm{H}$ (Berger and Roth, 1975; Berger, 1970). Biogenic carbonate deposition is, in contrast, characterized by a negative correlation between shell supply and preservation. Although tests may be abundantly supplied in high fertility areas, they are typically destroyed by associated carbon dioxide development. Comparable destruction of planktonic foraminifers has also been observed in fertile upwelling areas. Net accumulation of carbonate on the deep ocean floor is very largely determined by the carbonate compensation depth (CCD) where rate of supply and rate of dissolution are approximately equal (Bramlette, 1961). The position of the $\mathrm{CCD}$ has varied through geological time and then, as today, may have been at different depths in the world's oceans (fig. I of Berger and Winterer, 1974). The CCD today rises rapidly toward the continents, reflecting greatly increased dissolution due, perhaps, to increased carbon dioxide development associated with the greater supply of organic matter and the activity of benthic organisms (Berger and Winterer, 1974; Thiede, 1973). The present North Atlantic Ocean is characterized by carbonate sedimentation and a deep carbonate compensation depth reflecting the young warm waters that are depleted in nutrients and poor in carbon dioxide. In contrast, the Pacific has relatively shallow compensation levels whereas its deep waters are relatively old and rich in carbon dioxide (Berger, 1970).

Variations in the supply of biogenic silica and carbonate as well as in the carbonate compensation depth can, therefore, be regarded as monitors of changing ocean chemistry that may be modified by proximity to a continent. 
END OF

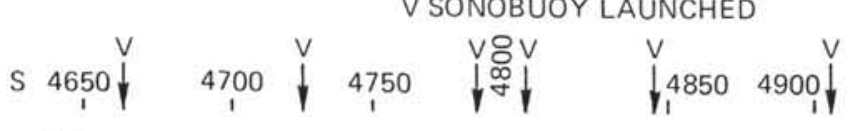
$4950 \downarrow$
SONOBUOY SIGNAL
0.0
$5000 \downarrow 5050 \downarrow \downarrow 5100$

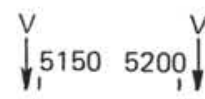
$5250 \downarrow 5300 \downarrow \frac{1}{1} 5350 \mathrm{~N}$

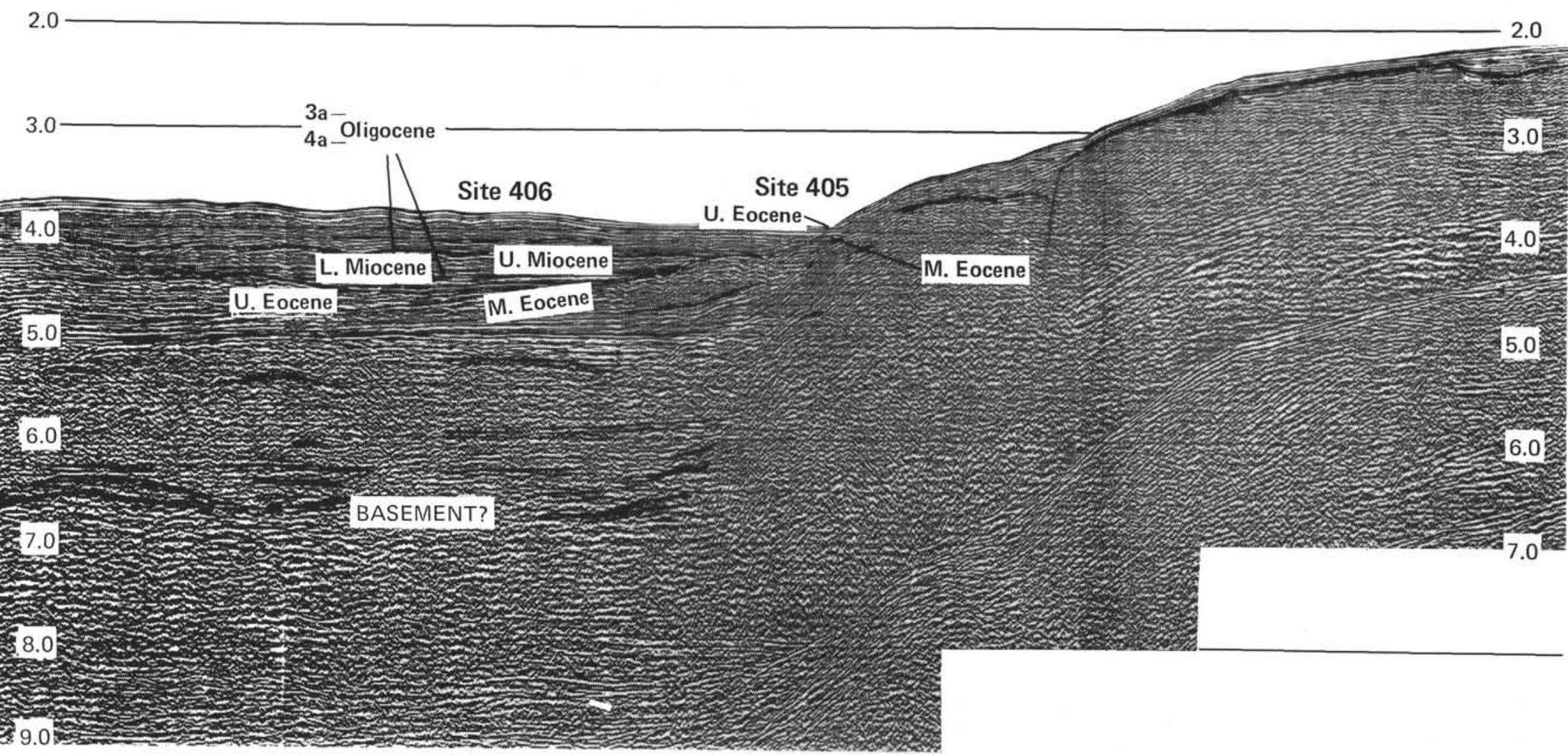

Figure 10. Seismic reflection profile through Sites 405 and 406 . Note the erosional unconformity between the middle and late Eocene and the marked discontinuity and change in seismic character between the early and late Miocene. 


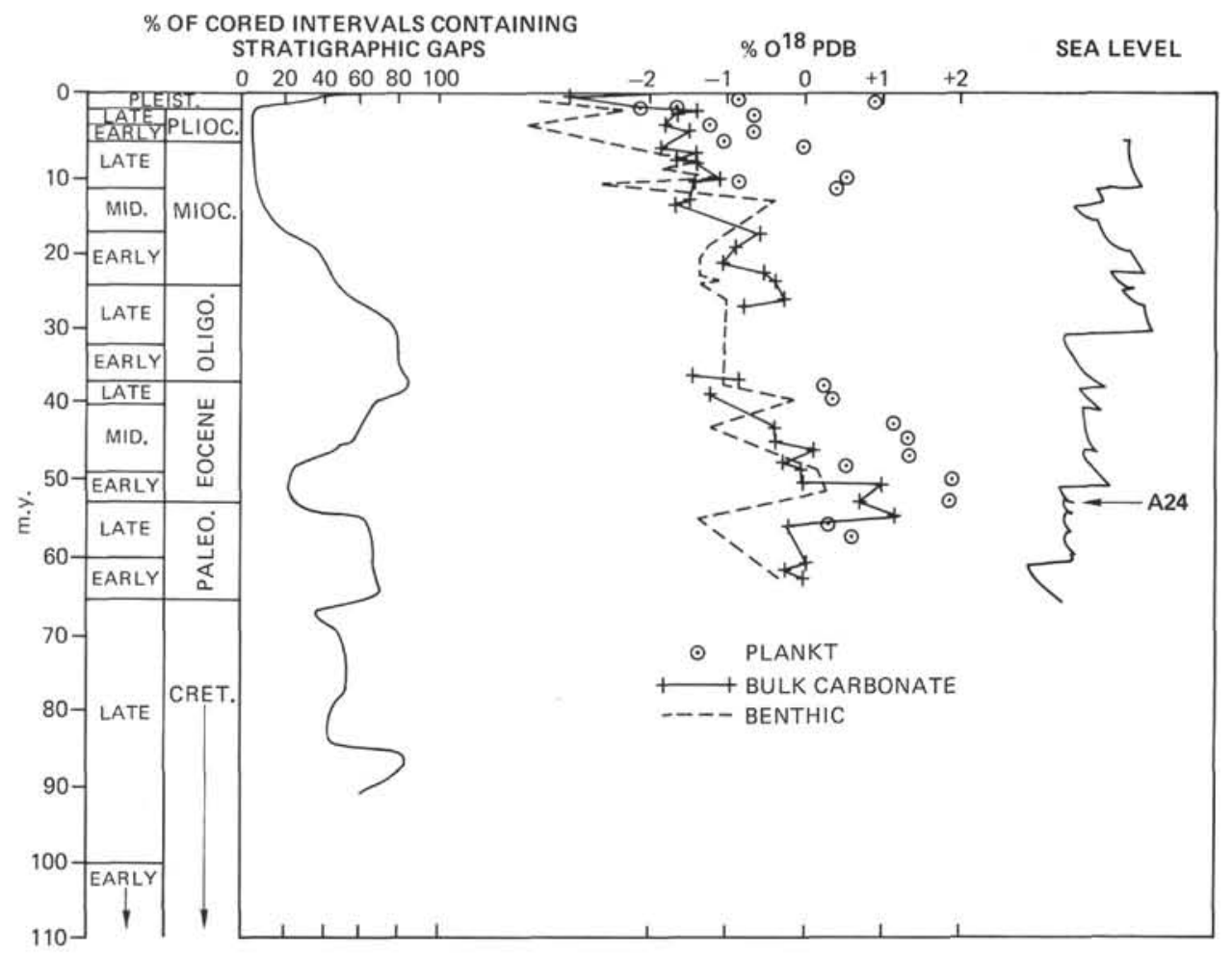

Figure 11. Comparison of per cent of cored intervals containing stratigraphic gaps, the $\delta O^{18}$ paleotemperature record of Hole $400 \mathrm{~A}$ and the global sea level curve of Vail et al. (1977).

Quantitative determinations of variations through the Cenozoic of the CCD have been made for the Atlantic by Berger and von Rad (1972) and by van Andel (1975), using back-tracking methods. Such methods cannot be applied to determine the depth of the CCD in Biscay because Site 400 reached its present depth in Paleocene time (Schnitker, this volume; Montadert, Roberts, et al., 1977, this volume). Nonetheless, a qualitative assessment can be obtained from the site data and compared with the quantitative data of the above authors. Their data show significant shoaling of the CCD in middle-late Miocene and during Eocene time. This depth is considerably shallower than both past and present depths at Site 401 and Hole 402A. Although some shoaling of the CCD close to the margin can be invoked, absence of solution of these sites indicates that the CCD did not intersect the margin at these depths. At Hole 400A, however, situated in 4000 meters depth throughout the Cenozoic, maximum solution of nannofossil and foraminiferal assemblages is shown as a decrease in carbonate (Figure 15) during the late Miocene and during middle and late-early Eocene, indicating a rise in the CCD. In contrast, good preservation of assemblages of Paleocene age indicates a fall in the CCD at that time (Figure 16). Although no quantitative description of CCD variations on the Biscay margin can be given, it is important to note that the variations are approximately coeval with those observed elsewhere in the Atlantic. Clearly, passive margins can be used as quantitative monitors of CCD variations in much the same manner as mid-ocean ridges, provided the subsidence history is known accurately.
An alternative monitor of solution is provided by the relative sedimentation rates of biogenous silica and carbonate. If the supply of biogenous silica and carbonate can be validly regarded as constant for adjacent deep and shallow sites on margins, the net accumulation of silica at deep sites also reflects the preservation of carbonate and therefore dissolution at depth. Accumulation of biogenous silica based on smear-slide determinations was highest in Eocene, Oligocene, and Miocene time, independently suggesting that the CCD was elevated between late Oligocene and early Miocene time and during the early-middle Eocene (Figure 14). These changes are qualitatively in agreement with those deduced for the Pacific and the Atlantic by van Andel et al. (1975) and van Andel (1977).

The rate of supply of biogenous silica and carbonate is also a function of the fertility or nutrients of ocean water. Changes in this rate through time, therefore, indirectly reflect variations in nutrient supply and thus oceanic turnover. A useful monitor of changes in organic productivity is provided by carbon isotope ratios, although continental organic production may also be important (Shackleton, 1977). Increases in organic productivity result in withdrawal of carbonate from the oceanic reservoir, forcing the oceanic reservoir toward the lighter isotope. Maxima in the carbon isotope curve correlate with periods of carbonate deposition where minima apparently correlate with periods of enhanced silica deposition (Figure 15). The peaks in the carbon isotope curve during Eocene and Miocene time correlate fairly well with rises in the CCD (van Andel et al., 


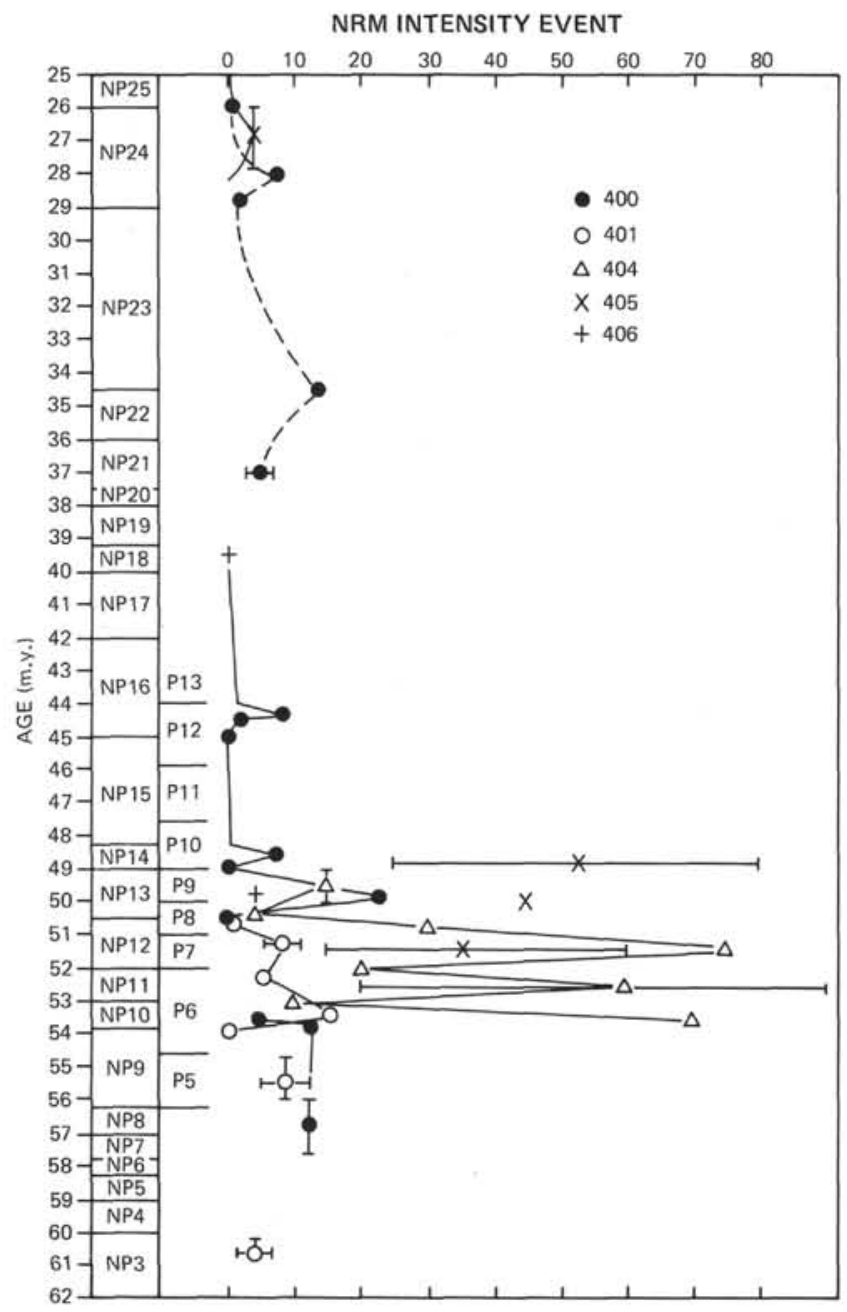

Figure 12. Intensity of natural remanent magnetization plotted against geological time (NRM data from Hailwood, this volume).

1977). It is also noteworthy that the minima in the carbon isotope ratio curves coincide with the Oligocene temperature minima for example (Figures 16, 17). However, the peaks, perhaps due to sampling intervals for oxygen and carbon isotope measurements, do not quite coincide with the warming episodes observed during the late Oligocene and during the early Eocene (Figures 8, 17). These changes are also revealed by marked lithological breaks. At Hole $400 \mathrm{~A}$ for example, brownish marly chalks of early-middle Eocene age give way to greenish gray siliceous mudstones marking increasing depth of the CCD and perhaps a change in oxidizing conditions. The change is accompanied by an increase in NRM. During lower and middle Oligocene time, a comparable change took place at Hole 400A. Periods of high silica production indicated by siliceous chalks and diatomites took place during late Eocene, Oligocene, and early Miocene time at Site 406.

Changes in carbon isotope ratio, paleotemperature, silica accumulation, and the CCD observed on northeast Atlantic passive margins thus show a broad correlation most easily related to ocean circulation changes. Changes in the global chemistry and circulation of ocean waters have, therefore, profoundly influenced the deposition and facies of margin sediments. The correlation between shoaling of the CCD, silica production, and warmer paleotemperatures is particularly noteworthy. Slower circulation rates in the World Ocean reflected by decreased temperature gradients would have led to slower turnover of nutrients, and the increased residence time of deep water would have allowed them to become saturated with respect to opal and carbon dioxide (Fischer and Arthur, 1977). One consequence may have been higher productivity of both carbonate and silica due to the increased fertility caused by upwelling of deep water. The upwelling which may have been enhanced by the strong topographic relief at sites in both Biscay and Rockall may have resulted in deposition of the unusual diatomites found at Site 406. Enhanced silica accumulation may have taken place due to basin-wide deviation of the CCD, due to saturation of the deep water with respect to carbon dioxide and local elevation due to upwelling along the margin. The relationship between paleotemperatures and oceanic turnover rates revealed by hiatuses was discussed earlier. These appear to coincide with the change from warm to colder temperatures, perhaps reflecting erosion and/or non-deposition associated with intensified circulation. We have also considered evidence in the Leg 48 data for a relationship between Cenozoic sea-level changes (Vail, 1977) and the processes discussed above. The most obvious correlation is in the early and late Miocene, although the late Oligocene transgression which led to deposition of calcareous ooze was undoubtedly associated with warmer water temperatures. The Eocene regression and the contemporaneous fall in the CCD may also be related. The correlation between sea-level rise and CCD elevation may reflect increased carbonate production in shelf waters that leads ultimately to saturation of ocean waters in carbon dioxide and a rise in the CCD.

\section{CONCLUSION}

It would be premature to draw from these limited data conclusions that encompass the North Atlantic Ocean and the world. Results from these first studies of margin paleoenvironments support the initial contention that the sedimentary record is another monitor of the changing paleoenvironment of the pelagic realm. Changes in silica and carbonate accumulation, the CCD, and paleotemperatures, all correlate reasonably well and attest to the importance of changes in ocean circulation and chemistry in influencing the nature and completeness of the record at passive margins. These changes are similar to those recorded by various workers for the Pacific and Antarctic oceans and emphasize the global nature of changes in the oceanic paleoenvironments. One conclusion of wider interest is the correlation between the most complete parts of the geological record with warmer conditions and an elevated CCD. If substantiated by further work, this may be of some use in understanding the distribution of siliceous and calcareous sediments at passive margins.

However, a key to a greater understanding of the evolution of the hydrographic regime along passive margins lies in documenting the relationship between changes in the hydrographic regime with time and depth due to circulation changes and the subsidence of the passive margin. A further 


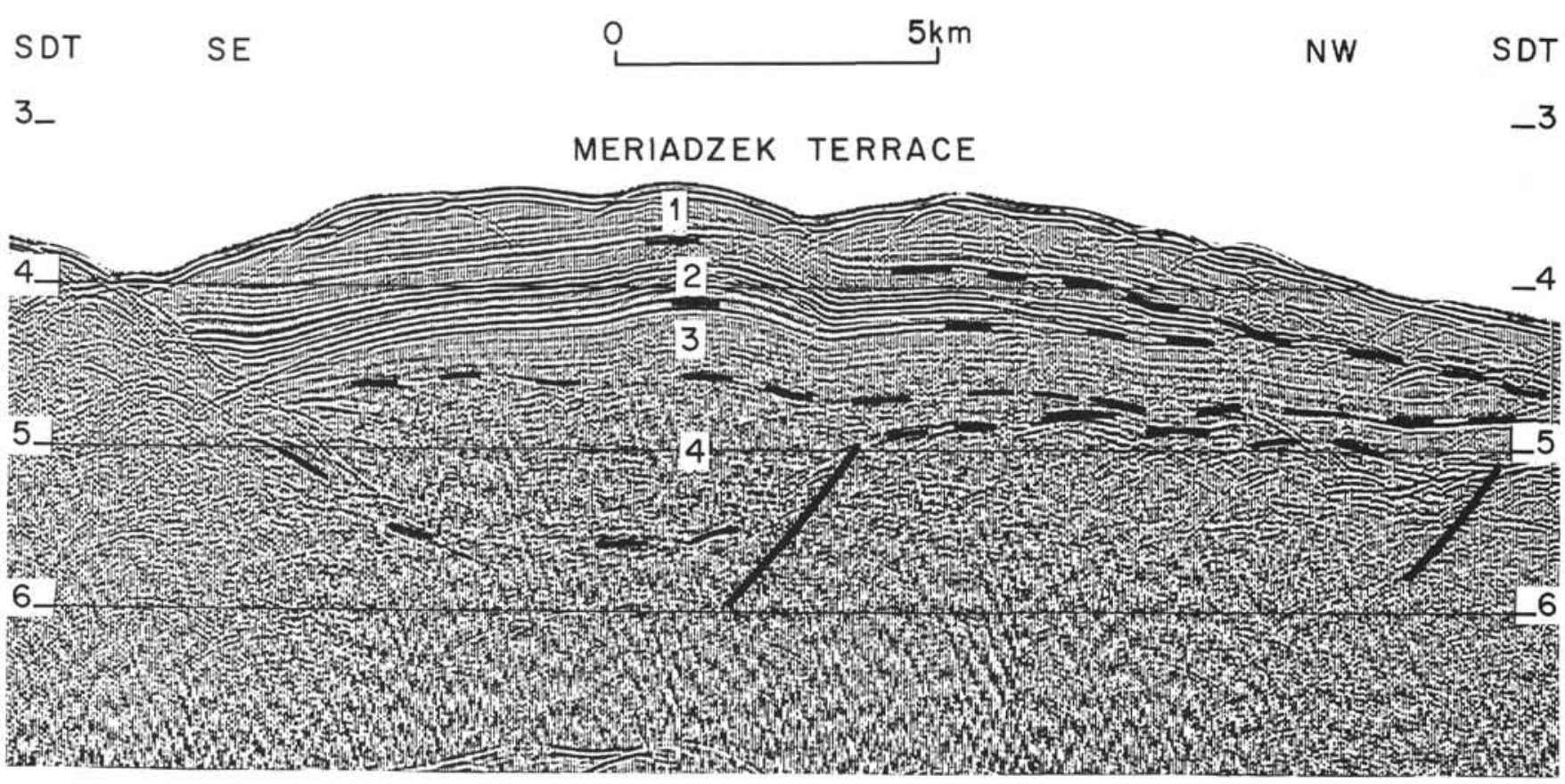

Figure 13. Intra Eocene/Oligocene erosion on the Meriadzek Terrace Bay of Biscay (from Montadert et al., this volume).

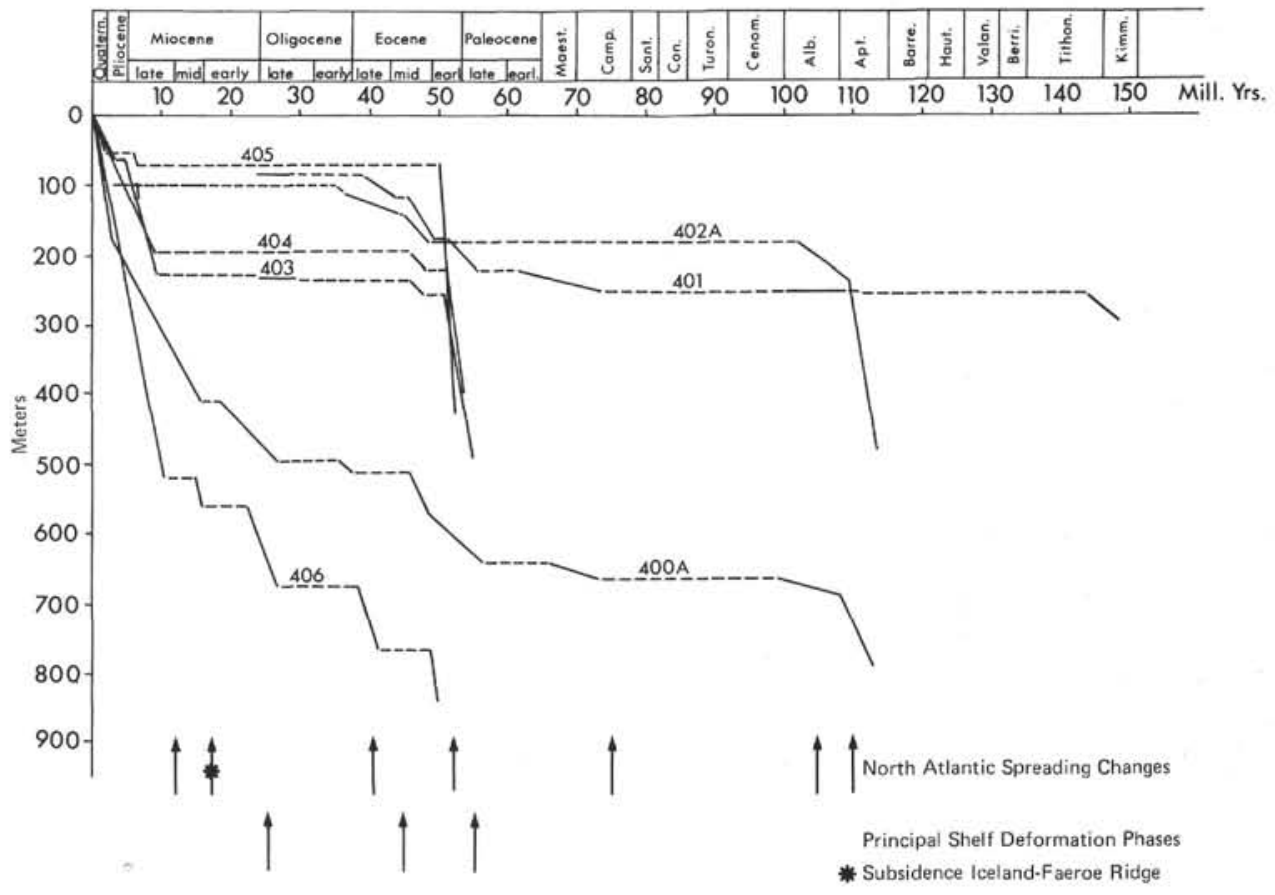

Figure 14. Sedimentation rates at Leg 48 sites and principal plate reorganizations in the North Atlantic Ocean for the Cenozoic. Principal determination phases on the shelf are also shown.

gap in our understanding is the link between margin environments and those of the inner shelf and continents. Related factors here include the influence of sea level changes and the orography of the continents. Until more data become available, it will remain difficult to distinguish cause from effect in building facies models of passive margin evolution.

\section{ACKNOWLEDGMENTS}

D.G. Roberts acknowledges support from the Department of Energy for his participation in studies of the Leg 48 results and the acquisition of seismic data. L. Montadert is grateful to the Institut Français du Pétrole, CNEXO and CEPM, which permitted the acquisition of data and his participation in Leg 48 studies. The authors are grateful to the Shipboard Party, R.B. Kidd, S.E. 


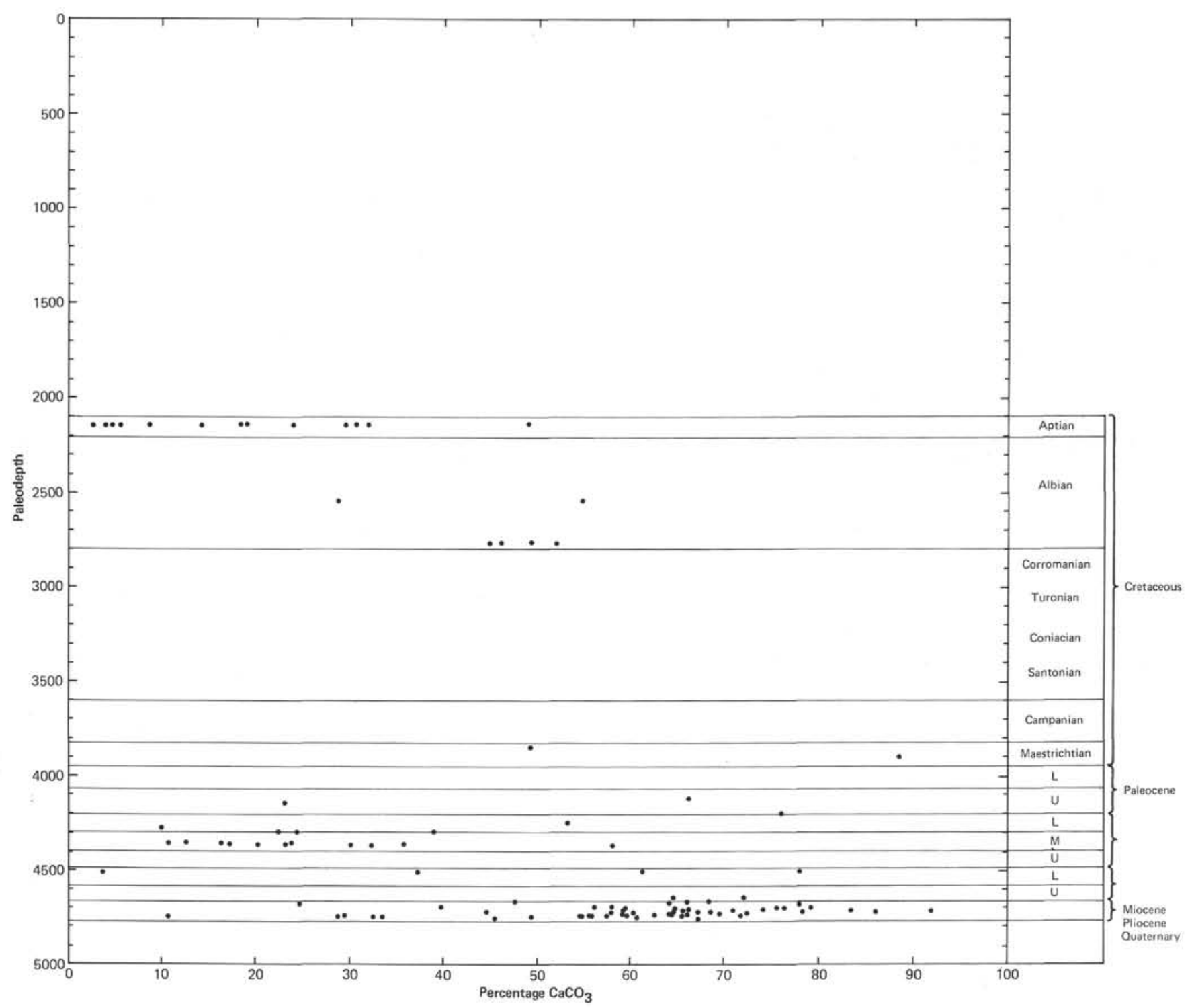

Figure 15. Carbonate percentages as a function of paleodepth at Hole $400 \mathrm{~A}$ (Montadert et al., this volume). Variations in percentages are interpreted as fluctuations in the CCD.

Calvert, C. Müller, R. Létolle, M. Arthur, and P. de Graciansky for many helpful and critical discussions.

\section{REFERENCES}

Auffret, G.A., Pastouret, L., and Kerbrat, R., 1975. Dynamique sedimentaire au bas de la marge continentale armoricaine: example de la rege Aegis, Paper V1-I, Ninth Int. Congr. Sediment., Nice.

Barker, P.F. and Burrell, J., 1977. The opening of the Drake Passage, Mar. Geol, v. 25, p. 15-34.

Beaudoin, B., 1977. Methodes d'analyse sédimentaire et reconstitution du basin: le Jurassique terminal — Berriasian des chaines subalpines mendionales these U.E.R., Sci. de la Terre, Unwersité de Caen.

Berger, W.H., 1970. Biogenous deep-sea sediments: fractionation by deep sea circulation, Geol. Soc. Am. Bull., v. 81, p. 1385-1402.

Berger, W.H. and Roth, P.H., 1975. Oceanic micropaleontology: progress and prospect, Rev. Geophys. Space Phys., v. 13, p. 561-585.
Berger, W.H. and von Rad, U., 1972. Cretaceous and Cenozoic sediments from the Atlantic Ocean. In Hayes, D.E., Pimm, A.C., et al., Initial Reports of the Deep Sea Drilling Project, v. 14: Washington (U.S. Government Printing Office), p. 787-954.

Berger, W. and Winterer, E., 1974. Plate stratigraphy and the fluctuating carbonate line: Pelagic sediments on land and under the sea, Int. Assoc. Sedimentol., v. 1, p. 11.

Berggren, W. and Hollister, C.D., 1974. Paleogeography, paleobiogeography and the history of circulation in the Atlantic Ocean, Studies in Paleoceanography, SEPM Publ. 20, p. 126-186.

Birkelund, T. and Perch-Nielsen, K., 1976. Late PaleozoicMesozoic evolution of central East Greenland. In Escher, A. and Watts, W.S. (Eds.), The geology of East Greenland: Copenhagen (Geological Survey of Greenland), p. 304-339.

Boersma, A. and Shackleton, N.J., 1977. Oxygen and carbon isotope record through the Oligocene DSDP Site 357. In Supko, P.R., Perch-Nielsen, K., et al., Initial Reports of the Deep Sea Drilling Project, v. 39: Washington (U.S. Government Printing Office), p. 911-924. 
SEDIMENTATION RATES AND PALEOTEMPERATURES

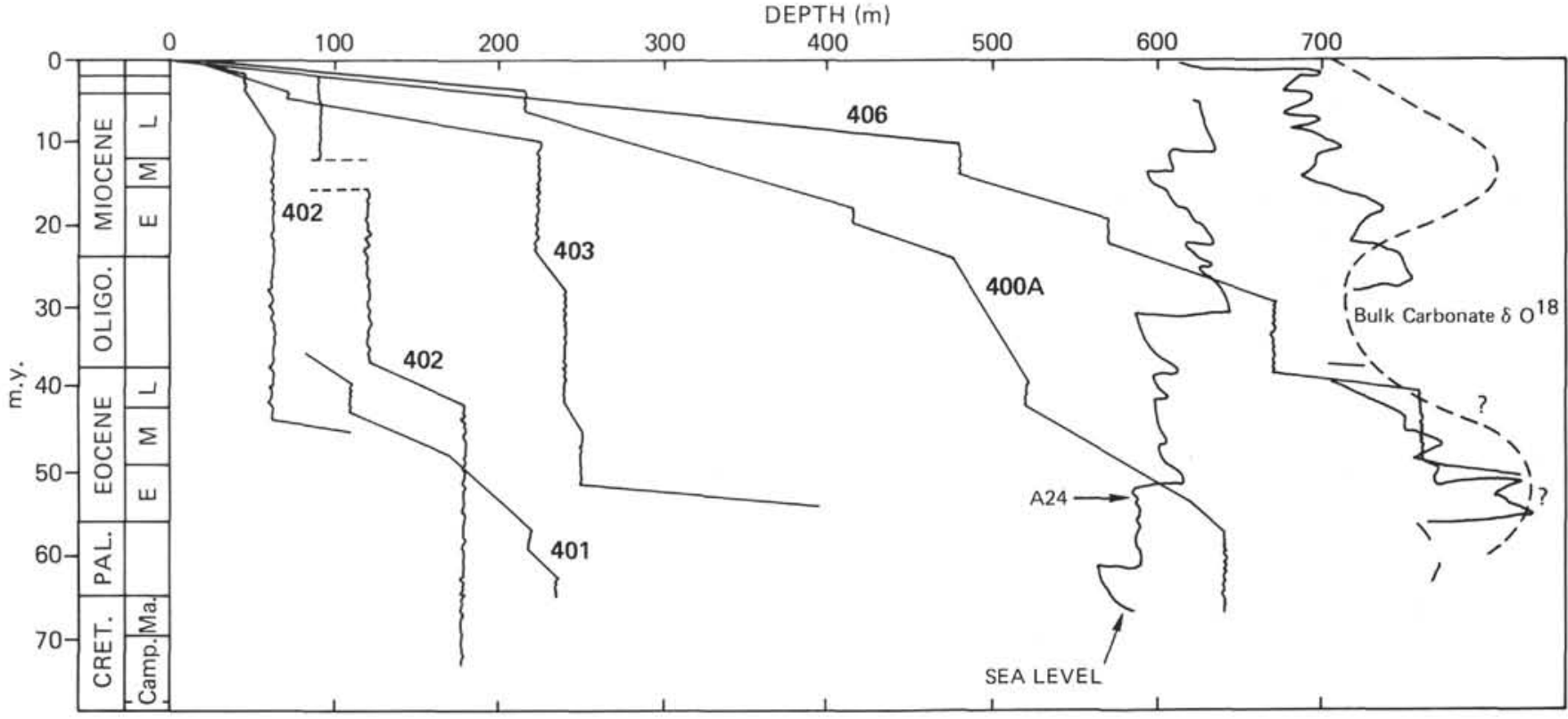

Figure 16. Sedimentation rates at Leg 48 sites, $\delta O^{18}$ data and generalized variations in the CCD during the Cenozoic (after van Andel, 1975 and Leg 48 data).

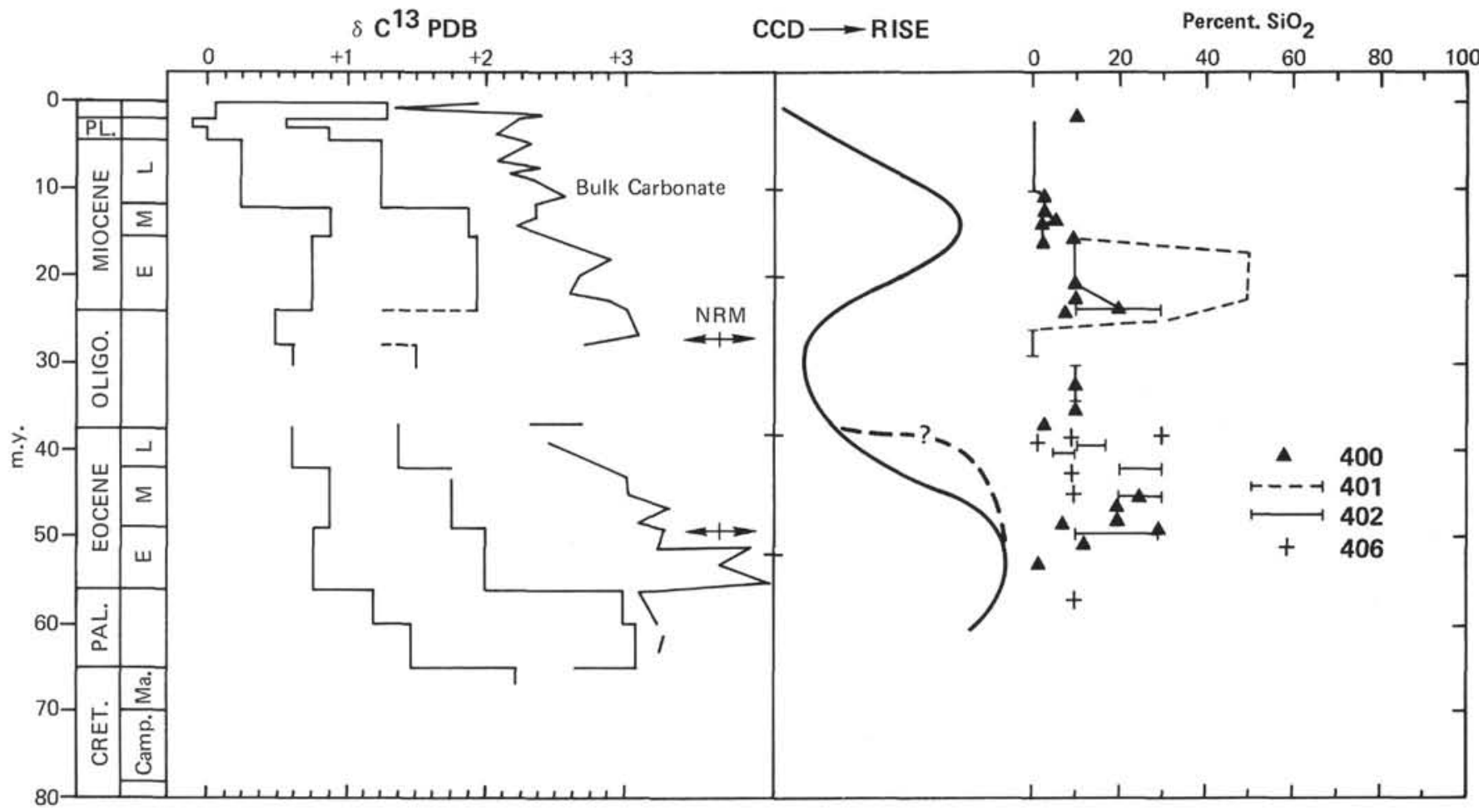

Figure 17. $\delta C^{13}$ isotopes, CCD variations and biogenic silica (from smear slides). CCD data from van Andel, 1975 and Leg 48 results, $\delta C 13$ isotopes after Létolle et al. (this volume). NRM: natural remanent magnetization peak.

Bott, M.H.P., Browitt, C.W.A., and Stacey, A.P., 1971. The deep structure of the Iceland-Faeroes Ridge, Mar. Geophys. Res., v. 1, p. 328-351.

Bott, M.H.P., Sunderland, J., Smith, P.J., Casten, U., and Saxov, S., 1974. Evidence for continental crust beneath the Faeroe Islands, Nature, London, v. 248, p. 202-204.
Bramlette, M.H., 1961. Pelagic sediments. In Sears, M. (Ed.), Oceanography:Am. Assoc. Adv. Sci.Publ., v. 67, p. 345-366.

Buchardt, B., 1977. Oxygen isotope paleotemperatures from the Tertiary North Sea and a 30 million year climatic periodicity, Dansk. Met. Inst. Clim. Papers, v. 4, p. 243-248. 
Charig, A.J., 1973. Kurten's theory of ordinal variety and the number of the continents. In Tarling, D.H. and Runcorn, S.K. (Eds.), Implications of continental drift for the earth sciences: London (Academic Press), v. 1, p. 229-244.

Cheetham, A.H. and Hakonnsen, E., 1971. Preliminary report on Bryozoa, Site 117. In Laughton, A.S., Berggren, W.A., et al., Initial Reports of the Deep Sea Drilling Project, v. 12: Washington (U.S. Government Printing Office), p. 432-441.

Crease, J., 1965. The flow of Norwegian Sea water through the Faeroe Bank Channel, Deep-Sea Res., v. 12, p. 143-150.

Davies, T.A., Weser, O.E., Luyendyk, B.P., and Kidd, R.B., 1974. Unconformities in the sediments of the Indian Ocean, Nature, London, v. 253, p. 15-19.

de Graciansky, P.C. and Genet, P.Y., in press. Sedimentological study of Cores 138-156 (upper Hauterivian to Lower Cenomanian) - an attempt at reconstruction of paleoenvironments. In Ryan, W.B.F., Sibuet, J.C., et al., Initial Reports of the Deep Sea Drilling Project, v. 47, Part 2: Washington (U.S. Government Printing Office).

Dietrich, G., Kalle, K., Krauss, W., and Siedler, G., 1975. Allgemeine Meereskunde: Eine Einfuhrung in dio Ozenographie: Berlin (Gebruder Borntraeger).

Ellett, D.J. and Roberts, D.G., 1973. The overflow of Norwegian Sea water across the Wyville-Thomson Ridge, Deep-Sea Res., v. 20 , p. $819-835$.

Featherstone, P.S., Bott, M.H.P., and Peacock, J.H., 1977. Structure of the continental margin of south eastern Greenland, Geophys. J., v. 48, p. 15-27.

Fischer, A.G. and Arthur, M. 1977. Secular variations in the pelagic realm, deep-water carbonate environments, SEPM Publ. 25, p. 19-50.

Haq, B.U., Premoli-Silva, I., and Lohmann, G., 1977. Calcareous plankton paleobiogeographic evidence for major climatic fluctuations in the early Cenozoic Atlantic Ocean, $J$. Geophys. Res., v. 82, p. 3861-3876.

Jefferies, R.P.S., 1963. Fauna and environment in the lowest Turenian (Actinocamax plenus Subzone) of the Anglo-Paris Basin. In Nairn, A.E.M. (Ed.), Problems in paleoclimatology: London (Interscience Publishers).

Johnson, G.L., McMillan, N.J., and Egloff, J., 1975. East Greenland Continental margin: Canada's continental margins and offshore petroleum exploration, Can. Soc. Petrol. Geol. Mem., v. 4, p. 205-224.

Johnson, G.L., Vogt, P.R., and Schneider, E.D., 1971. Morphology of the north eastern Atlantic and Labrador Sea, Deutsch. Hydrog. Zeitschr., v. 24, p. 49-73.

Jones, E.J.W., Ewing, M., Ewing, J.I., and Eittreim, S., 1971. Influences of Norwegian Sea overflow water on sedimentation in the northern North Atlantic and Labrador Sea, J. Geophys. Res., v. 75, p. 1655-1680.

Kennett, J.P., 1977. Cenozoic evolution of Antarctic glaciation, the circum-Antarctic Ocean and their impact on global oceanography, J. Geophys. Res., v. 82, p. 3843-3860.

Kennett, J.P., Houtz, R.E., et al., 1975. Cenozoic paleoceanography in the southwest Pacific Ocean. Antarctic glaciation and the development of circum-Antarctic current. In Simpson, E., Schlich, R., et al., Initial Reports of the Deep Sea Drilling Project, v. 25: Washington (U.S. Government Printing Office), p. 1155 .

Kennett, J. P. and Shackleton, N.J., 1976. Oxygen isotopic evidence for the development of the psychrosphere $38 \mathrm{~m} . \mathrm{y}$. ago, Nature, v. 260, p. 513-515.

Kristoffersen, Y., 1978. Sea floor spreading and the early opening of the North Atlantic, Earth Planet. Sci. Lett.. v. 38, p. 273-290.

Laughton, A.S., 1972. South Labrador Sea and the evolution of the North Atlantic, Nature, London, v. 232, p. 612-617.
Laughton, A.S., Berggren, W., et al., 1972. Initial Reports of the Deep Sea Drilling Project, v. 12: Washington (U.S. Government Printing Office).

Lee, A.J., 1974. Oceanic circulation of the North Atlantic region. In Haiden-Jones, R. (Ed.), Sea fisheries research: London (Elek Science), p. 1-30.

Lee, A. and Ellett, D.J., 1965. On the contribution of overflow water from the Norwegian Sea to the hydrographic structure of the North Atlantic Ocean, Deep-Sea Res., v. 12, p. 129-142. , 1967. On the water masses of the Northeast Atlantic Ocean, Deep-Sea Res., v. 14, p. 183-190.

Le Pichon, X., Hyndman, R., and Pautot, G., 1972. Geophysical study of the opening of the Labrador Sea, J. Geophys. Res., v. 76 , p. $4742-4749$.

Le Pichon, X., Sibuet, J.C., and Francheteau, J., 1977. The bit of the continents around the North Atlantic Ocean, Tectonophysics, v. 38, p. 169-209.

Lisitzin, A.P., 1972. Sedimentation in the World Ocean, SEPM Spec. Publ. 17, p. 218.

Montadert, L., Roberts, D.G., et al., 1977. Rifting and subsidence on North East Atlantic passive margins, Nature, London, v. 277, p. 305-309.

Moore, T.C., 1972. Deep Sea Drilling Project: Successes, failures, proposals, Geotimes, v. 17, p. 27-31.

Moore, T.C. and Heath, G.R., 1977. Survival of deep sea sedimentary sections, Earth Planet. Sci. Lett., v. 37, p. 71-80.

Müller, C., 1976. Tertiary and Quaternary calcareous nannoplankton in the Norwegian-Greenland Sea DSDP. Leg 38. In Talwani, M., Udintsev, G., et al., Initial Reports of the Deep Sea Drilling Project, v. 38: Washington (U.S. Government Printing Office), p. 823-842.

Olivet, J.L., Le Pichon, X., Monti, S., and Siehler, B., 1974. Charlie-Gibbs Fracture Zone, J. Geophys. Res., v. 79, p. 2059-2073.

Pimm, A.C., Hayes, D.E., et al., 1972. Initial Reports of the Deep Sea Drilling Project, v. 14: Washington (U.S. Government Printing Office).

Pitman, W.C., in press. Relationship between sea level change and stratigraphic sequences, Geol. Soc. Am. Bull.

Pitman, W.C. and Talwani, M., 1972. Sea floor spreading in the North Atlantic, Geol. Soc. Am. Bull., v. 83, p. 619-646.

Rabinowitz, P. and La Brecque, J., in press. The Mesozoic South Atlantic Ocean and evolution of its continental margins, Tectonophysics.

Roberts, D.G., 1974, Structural development of the British 1sles, the continental margin and the Rockall Plateau. In Bark, C.A. and Drake, C.L. (Eds.), The geology of continental margins: New York (Springer-Verlag), p. 343-360.

, 1975. Marine geology of the Rockall Plateau and Trough, Phil. Trans. Roy. Soc. London, v, 7, p. 447-509.

Roberts, D.G. and Jones, M.T., 1975. Magnetic anomalies and the early evolution of the N.E. Atlantic, Abstr. Mtg. Europ. Geol. Soc., Reading, Sept. 8-12, 1975.

Ruddiman, W.B., 1972. Sediment distribution on the Reykjanes Ridge: seismic evidence, Geol. Soc. Am. Bull., v. 83, p. 2039-2062.

Ryan, W.B.F. and Cita, M., 1977. Ignorance concerning episodes of oceanwide stagnation, Mar. Geol., v. 23, p. 197-215.

Ryan, W.B.F., Sibuet, J.C., et al., 1976. Passive continental margin, Geotimes, v. 21, p. 21-24.

Savin, S.M., 1977. History of the Earth's surface temperature during the past 100 million years. Ann. Rev. Earth. Planet. Sci.: Palo Alto (Annual Reviews Inc.), p. 319-356.

Schlanger, S.O. and Jenkyns, H.C., 1976. Cretaceous oceanic anoxic events: causes and consequences, Geol. Mijnb., v. 55, p. 175-184. 
Sclater, J.G., Hellinger, S., and Tapscott, C., 1977. Paleobathymetry of the Atlantic Ocean from the Jurassic to the present, J. Geol., v. 85, p. 509-551.

Searle, R.C. and Whitmarsh, R.B., 1978. The stricture of King's Trough, Northeast Atlantic from bathymetric, seismic, and gravity studies, Geophys. J., v. 53, p. 259-287.

Shackleton, N.J., 1977. Carbon-13 in Uvigerina: tropical rain forest history and the fate of fossil $\mathrm{CO}_{2}$ equatorial Pacific carbonate dissolution cycles. In Andersen, N.R. and Malahoff, A. (Eds.), The fate of fossil fuel $\mathrm{CO}_{2}$ in the oceans: New York (Plenum Press), p. 401-427.

Shackleton, N.J. and Kennett, J.P., 1975. Paleotemperature history of the Cenozoic and the unitration of Antarctic glaciation: oxygen and carbon-isotope analyses in DSDP Sites 227, 279, and 281. In Kennett, J.P., Houtz, R.E., et al., Initial Reports of the Deep Sea Drilling Project, v. 29: Washington (U.S. Government Printing Office), p. 743-755.

Srivastava, S.P. 1978. Evolution of the Labrador Sea and its bearing on the early evolution of the North Atlantic, Geophys. J., v. 52, p. 313-357.

Surlyk, F., 1978. Jurassic basin evolution of East Greenland, Nature, London, v. 274, p. 130-133.

Sverdrup, H.U., Johnson, M.W., and Fleming, R.H., 1942. The oceans: New York (Prentice-Hall).

Swallow, J.C., Gould, J.W., and Saunders, P.W., 1977. Evidence for a poleward eastern boundary current in the North Atlantic Ocean, ICES, Paper C.M., 1977/C. 32.

Talwani, M., Eldholm, O., 1977. Evolution of the Norwegian-Greenland Sea, Geol. Soc. Am. Bull., v. 88, p. 969-999.

Talwani, M., Udintsev, G., et al., 1976. Initial Reports of the Deep Sea Drilling Project, v. 38: Washington (U.S. Government Printing Office).

Thiede, J., in press. Paleoceanography, margin stratigraphy and paleophysiography of the Tertiary North Atlantic and Norwegian-Greenland Seas, Phil. Trans. Roy. Soc. London. , 1973. Planktonic foraminifera in hemipelagic sediments. Shell preservation off Portugal and Morocco, Geol. Soc. Am. Bull., v. 84 , p. $2749-2754$.
Thiede, J. and van Andel, J., 1977. The paleoenvironment of anaerobic sediments in the late Mesozoic South Atlantic Ocean, Earth Planet Sci. Lett., v. 33, p. 301-309.

Tissot, B., in press. Organic matter in Cretaceous sediments of the North Atlantic: contribution to sedimentology and paleogeography, Second Maurice Ewing Mem. Symp. Proc.

Tissot, B., Durand, B., Espitalie, J., and Combaz, A., 1964. Influence of the nature and diagenesis of organic matter in the formation of petroleum, Am. Assoc. Petrol. Geol. Bull., v. 58, p. 499-506.

Vail, P.R., Mitchum, R.M., and Thompson, S., 1977. Global cycles of relative changes of sea level, Am. Assoc. Petrol. Geol. Mem. 26., p. 83-98.

van Andel, T.H., 1975. Mesozoic/Cenozoic calcite compensation depth and the global distribution of calcareous sediments, Earth Planet. Sci. Lett., v. 26, p. 187-195.

van Andel, T.H., Heath, G.R., and Moore, T.C., 1975. Cenozoic history and paleoceanography of the central equatorial Pacific, Geol. Soc. Am. Mem. 143, p. 134.

van Andel, T.H., Thiede, J., Sclater, J.G., and Hay, W.W., 1977. Depositional history of the South Atlantic during the last 125 million years, J. Geol, v. 85, p. 651-698.

Vogt, P.R., 1972. The Faeroe-Greenland-Iceland Ridge and the Western Boundary undercurrent, Nature, London, v. 239, p. 79-81.

Vogt, P.R. and Avery, O.E., 1974. Detailed magnetic surveys in the North East Atlantic and Labrador Sea, J. Geophys. Res., v. 79 , p. 363-389.

Williams, C.A., 1975. Sea floor spreading of the Bay of Biscay and its relationship to the North Atlantic, Earth Planet. Sci. Lett., v. 24 , p. $440-456$.

Worthington, L.V., 1970. The Norwegian Sea as a Mediterranean Basin, Deep-Sea Res., v. 17, p. 77-84.

Worthington, L.V. and Wright, W.R., 1970. North Atlantic Ocean atlas of potential temperature and salinity in the deep water, Woods Hole Oceanogr. Inst. Atlas, Ser 2. 